\title{
Oncogenic kinases and perturbations in protein synthesis machinery and energetics in neoplasia
}

\author{
Oro Uchenunu1,2, Michael Pollak ${ }^{1,2,3}$, Ivan Topisirovic ${ }^{1,2,3,4}$ and Laura Hulea ${ }^{1,3}$ \\ 'Lady Davis Institute, SMBD JGH, McGill University, Montreal, Quebec, Canada \\ 2Department of Experimental Medicine, Montreal, Quebec, Canada \\ ${ }^{3}$ Gerald Bronfman Department of Oncology, Montreal, Quebec, Canada \\ 4Biochemistry Department, McGill University, Montreal, Quebec, Canada
}

Correspondence should be addressed to L Hulea: laura.hulea@mail.mcgill.ca

\begin{abstract}
Notwithstanding that metabolic perturbations and dysregulated protein synthesis are salient features of cancer, the mechanism underlying coordination of cellular energy balance with mRNA translation (which is the most energy consuming process in the cell) is poorly understood. In this review, we focus on recently emerging insights in the molecular underpinnings of the cross-talk between oncogenic kinases, translational apparatus and cellular energy metabolism. In particular, we focus on the central signaling nodes that regulate these processes (e.g. the mechanistic/mammalian target of rapamycin MTOR) and the potential implications of these findings on improving the anti-neoplastic efficacy of oncogenic kinase inhibitors.
\end{abstract}

\author{
Key Words \\ - protein synthesis \\ - metabolism \\ - cancer \\ - MTOR \\ oncogenic kinases
}

Journal of Molecular Endocrinology (2019) 62, R83-R103

\section{Introduction}

Protein synthesis is a complex process involving the interaction of ribosomes, mRNAs, tRNAs and auxiliary proteins known as translation factors (Hershey et al. 2012). Protein synthesis must be tightly regulated as it affects crucial cellular processes (e.g. proliferation, growth, differentiation and development) (Hershey et al. 2012). Dysregulated mRNA translation is implicated in most hallmarks of cancer including aberrant cell proliferation, survival, angiogenesis and cellular energetics (Johnson et al. 1976, Kevil et al. 1996, Larsson et al. 2006, Larsson et al. 2007, Hanahan \& Weinberg 2011, Topisirovic \& Sonenberg 2011). The observation that protein synthesis is altered in malignant cells is not recent. Neoplastic cells were shown to have enlarged and abnormally shaped nucleoli, which are ribosome-producing factories, over a century ago (Giuseppe 1896). A positive correlation has been observed between cancer cell proliferation and the rate of protein synthesis (Johnson et al. 1976).
Moreover, the function and/or the expression of several components of the translation machinery is perturbed in cancer cells (Ruggero 2013). Oncogene activation and the inactivation of tumor suppressors, which drive the development of cancer, converge on the translation machinery (Ruggero 2013). Dysregulation of the components of the translational machinery results in translational reprogramming that favors the development of drug resistance, angiogenesis, survival, proliferation and metastasis. For instance, high levels of eukaryotic translation initiator factor 4E (EIF4E (proteins written in bold are represented in the figures)) have been linked to increased cell cycle progression, neoplastic growth and chemoresistance (Byrnes et al. 2007, Larsson et al. 2007).

mRNA translation plays a central role in the regulation of gene expression, leading to immediate changes in protein levels (Sonenberg \& Hinnebusch 2009), which are required for adaptation to stress (Spriggs et al. 2010,

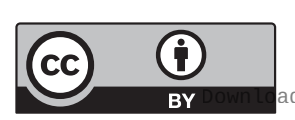

This work is licensed under a Creative Commons Attribution 4.0 Unported License. 
Guan et al. 2017). The importance of gene expression regulation at the translational level is evident as steadystate mRNA levels are thought to have low concordance with the proteome (Schwanhausser et al. 2011), although the scope of this phenomenon is still being discussed (Li et al. 2014b). mRNA translation is one of the most energy demanding cellular processes, requiring 20-30\% of the total ATP (Buttgereit \& Brand 1995, Rolfe \& Brown 1997). Thus, in order to sustain elevated protein synthesis required for neoplastic growth, malignant cells must adjust their energy metabolism. MTOR is a key regulator of translation (Sonenberg \& Hinnebusch 2009). AMPactivated protein kinase (AMPK) acts as an intracellular energy sensor and is activated when nutrients or oxygen are in short supply and the ratio of cellular AMP to ATP is elevated (Kahn et al. 2005, Shaw 2009). Activated AMPK results in the downregulation of protein synthesis, which is accompanied by reduced cell growth and proliferation via the MTORC1 (mechanistic/mammalian target of rapamycin complex 1) signaling pathway (Shaw et al. 2004a). Consequently, the AMPK/MTORC1 signaling pathway links cellular energy status to mRNA translation rates.

It was discovered in the 1920s that cancer cells reprogram their metabolism and reduce glucose to lactate even in the presence of oxygen (Warburg 1925). Tumor cells exhibit elevated glucose uptake as well as lactate production when compared to normal tissues in the presence of oxygen (Warburg 1956). This metabolic reprogramming is referred to as the Warburg effect or 'aerobic glycolysis' (DeBerardinis et al. 2008, Hsu \& Sabatini 2008). Although the conversion of glucose to lactate through glycolysis produces far less ATP per glucose molecule than glucose catabolism through oxidative phosphorylation to carbon dioxide and water, during glycolysis ATP is produced at a faster rate, and this may be important to fuel the rapid proliferation of cancer cells (Vander Heiden et al. 2009, Locasale \& Cantley 2011, Shestov et al. 2014). Thus, increasing glucose uptake and glycolytic flux represents a strategy to quickly generate ATP (Pfeiffer et al. 2001). Importantly, glycolysis also fuels neoplastic growth through providing intermediates required for the biosynthesis of lipids, nucleotides, NADPH and amino acids (Lunt \& Vander Heiden 2011). Furthermore, the lactic acid produced as the end product of aerobic glycolysis has been found to favor cancel cell invasion (Smallbone et al. 2005), used as an alternate tricarboxylic acid cycle (TCA) carbon source (Faubert et al. 2017) and may interfere with local anti-cancer immune responses (Choi et al. 2013). The consumption of large amounts of glucose by cancer cells may also suppress the immune response by reducing the glucose concentration in the tumor microenvironment and depriving immune effector cells of glucose (Chang et al. 2015, Ho et al. 2015). Moreover, alterations in the tumor microenvironment (such as blood flow, oxygen and nutrient supply) in vivo can also contribute to metabolic plasticity (Jessani et al. 2004, Hsu \& Sabatini 2008, Dang et al. 2011).

In this review, we highlight recent findings related to the role of cancer-relevant signaling pathways in coordinating protein synthesis and metabolic activities in the cell. Furthermore, we speculate on the potential implication of these findings in improving the efficacy of current therapies and in developing future cancer therapeutics.

\section{PI3K/AKT - mechanisms of activation and regulation of metabolic functions}

The phosphatidylinositol-4,5-biphosphate 3-kinase (PI3K)/AKT/MTOR signaling pathway regulates many essential processes including cell growth, mRNA translation, proliferation, survival, apoptosis and metabolism (Yao \& Cooper 1995, Kauffmann-Zeh et al. 1997, Laplante \& Sabatini 2009b). Aberrant signaling via this pathway has been implicated in pathological conditions including diabetes and cancer, whereby its hyperactivation in general is tumor promoting (Laplante \& Sabatini 2012, Porta et al. 2014).

The PI3K/AKT signaling cascade is activated when receptor tyrosine kinases such as insulin receptors are bound by their ligands, including insulin and/or growth factors (Ruggero \& Sonenberg 2005) (Fig. 1). The extracellular binding of the ligands results in intracellular autophosphorylation of tyrosine residues on the receptors (Schlessinger 2002, Lemmon \& Schlessinger 2010). The phosphorylated tyrosine residues recruit PI3K to the membrane (Domchek et al. 1992). At the membrane, PI3K phosphorylates phosphatidyl inositol4,5-biphosphate $\left(\mathrm{PIP}_{2}\right.$ ) to produce phosphatidyl inositol3,4,5-triphosphate ( $\mathrm{PIP}_{3}$ ) (Fig. 1) (Cantley 2002). PIP 3 then acts as a second messenger and is responsible for translocating downstream signaling proteins such as AKT/protein kinase B (PKB) to the cell membrane where they are phosphorylated and activated by PDPK1 (3-phosphoinositide-dependent protein kinase 1) (Fig. 1) (Alessi et al. 1997, Fresno Vara et al. 2004). AKT is a serine/threonine protein kinase that regulates cell survival, growth and proliferation (Wan et al. 2007, Myers \& Cantley 2010). AKT carries out its functions

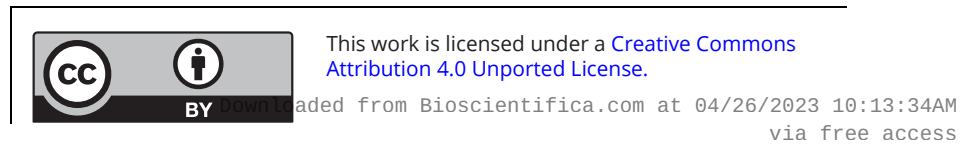




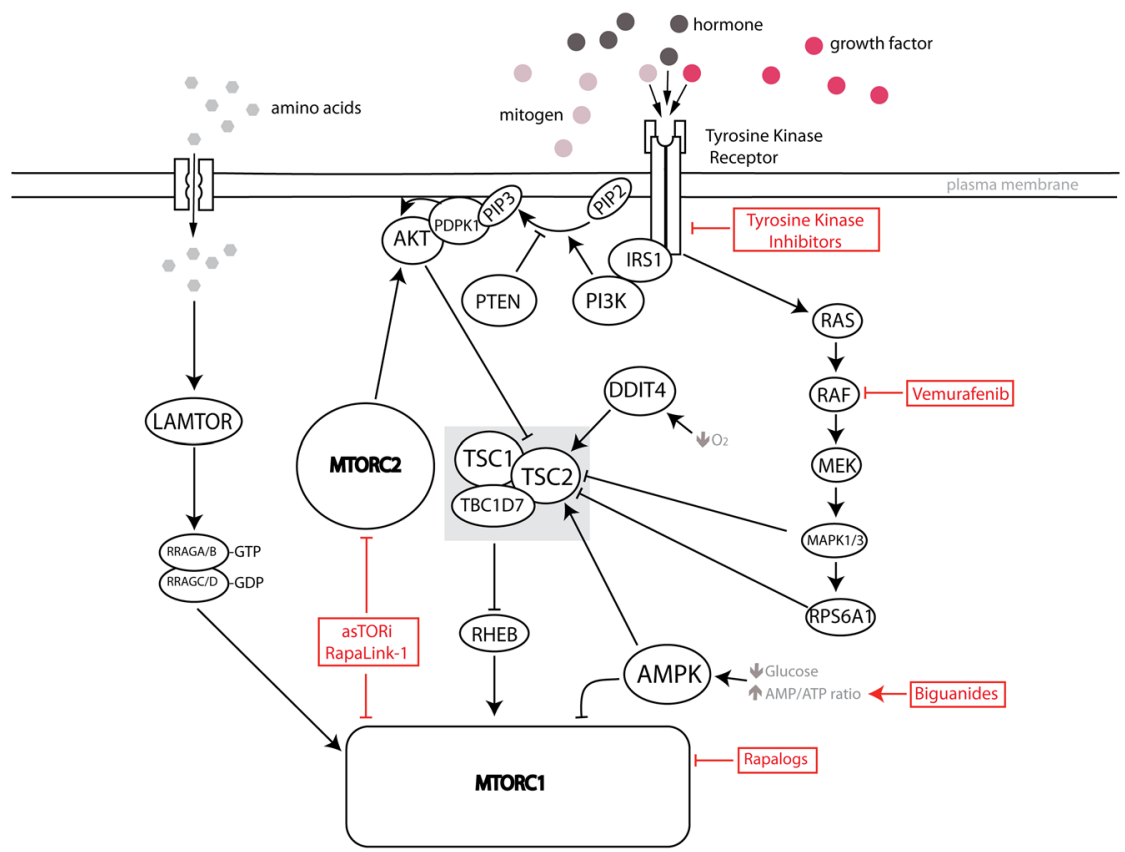

\section{Figure 1}

Representation of signaling pathways upstream of MTORC1. MTOR exists in two functionally and structurally distinct complexes: MTORC1 and MTORC2. MTORC1 is activated by hormones (e.g. insulin) or growth factors (e.g. EGF, FGF) via receptor tyrosine kinases. This sets off a signaling cascade leading to the activation of PI3K which inactivates TSC2 via AKT. In addition, TSC2 is inhibited by the MAPK/RSK pathway, and activated by DDIT4 and AMPK in response to hypoxia, and nutrient/energy depletion, respectively. TSC inactivation leads to MTORC1 activation, though the intermediary of RHEB. Amino acids stimulate LAMTOR, a GEF for the heterodimeric RRAG complex, which in turn activates MTORC1. Pharmacological inhibitors that potentially impact on the cross-talk between mTOR-dependent translational and metabolic programs are indicated. Further explanations are provided in the text. MTOR, mechanistic target of rapamycin kinase; MTORC1, mechanistic target of rapamycin complex 1; MTORC2, mechanistic target of rapamycin complex 2; EGF, epidermal growth factor; FGF, fibroblast growth factor; PI3K, phosphoinositide 3-kinase; TSC2, tuberous sclerosis complex 2; MAPK, mitogen-activated protein kinase; RSK, p90 ribosomal S6 kinase; DDIT4, DNA damage inducible transcript 4; AKT, protein kinase B; AMPK, AMP-activated protein kinase; RHEB, ras homolog, MTORC1 binding; LAMTOR, late endosomal and lysosomal adaptor and MAPK (mitogen-activated protein kinase) and MTOR (mechanistic target of rapamycin) activator; GEF, guanine nucleotide exchange factor; RRAG, ras-related GTP-binding protein.

through various downstream effectors including MTOR (Slomovitz \& Coleman 2012). A major negative regulator of AKT is PTEN (phosphatase and tensin homolog) (Stambolic et al. 1998), which catalyzes the conversion of $\mathrm{PIP}_{3}$ to $\mathrm{PIP}_{2}$ and acts as a tumor suppressor (Fig. 1). AKT activity is increased in various cancer types, either due to mutations or amplifications of the AKT1 gene or due to the dysregulation of upstream regulators (e.g. PTEN) and mitogenic factors (e.g. hormones, growth factors) (Cheng et al. 2005, Malanga et al. 2008).

The PI3K/AKT pathway has been implicated in glucose metabolism and lipid synthesis (Whiteman et al. 2002, Elstrom et al. 2004). Specifically, AKT has been shown to mediate the translocation of glucose transporter SLC2A4 (solute carrier family 2 member 4; GLUT4) to the plasma membrane (Kohn et al. 1996) and stimulate glycolysis through the phosphorylation and activation of 6-phosphofructo-2-kinase/fructose2,6-biphosphatse (PFKFB)(Deprez et al. 1997). It also indirectly stimulates glycogen synthase to produce glycogen through the phosphorylation and inactivation of glycogen synthase kinase 3 (GSK3) alpha and beta isoforms (Cross et al. 1995). In addition, AKT inhibits gluconeogenesis by phosphorylating and inhibiting forkhead box O1 (FOXO1) transcription factor (Accili \& Arden 2004). AKT has been implicated in activating ATPcitrate lyase (ACLY), an enzyme involved in fatty acid synthesis in adipocytes (Berwick et al. 2002). In addition to these findings highlighting the role of PI3K/AKT signaling pathway in glucose and lipid metabolism, the PI3K/AKT pathway affects cellular metabolic programs via the MTOR pathway (discussed in more detail below).

\section{MTOR}

MTOR is a conserved serine/threonine kinase that is part of the phosphoinositide kinase-related family, which stimulates anabolic processes in the cell, including lipid and protein synthesis (Wang \& Proud 2006, Laplante \& Sabatini 2009a). It integrates extracellular and intracellular signals emanating from environmental cues, nutrient availability and cellular energetic status (Liu et al. 2009,

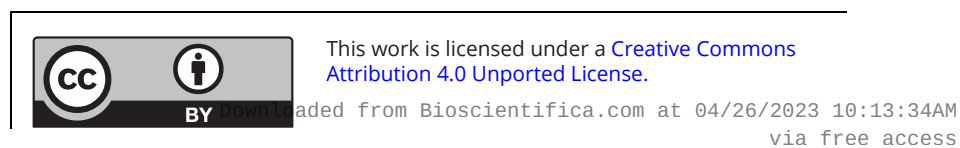


Zhou \& Huang 2011). In turn, it regulates cell growth, proliferation, protein synthesis, survival, autophagy and energy metabolism (Shimobayashi \& Hall 2014). MTOR is the catalytic subunit of two functionally and structurally distinct multiprotein complexes: MTORC1 and MTORC2. One of the main modulators of MTORC1 activity is the PI3K/AKT pathway (Hay \& Sonenberg 2004).

\section{Regulation of MTORC1 activity}

Upon activation of the pathway, AKT phosphorylates TSC complex subunit 2 (TSC2), which heterotrimerize with TSC complex subunit 1 (TSC1) and TBC1 domain family member 7 (TBC1D7) (Zech et al. 2016) (Fig. 1). Phosphorylation of TSC2 leads to the inhibition of the TSC complex. Since the TSC is a GTPase-activating protein (GAP) complex for the Ras homolog, enriched in brain (RHEB), the inhibition of TSC2 results in increased RHEB:GTP levels (Long et al. 2005, Sancak et al. 2007). GTP-bound RHEB activates MTORC1 (Fig. 1) (Long et al. 2005, Sancak et al. 2007).

In addition to growth factors, hormones and cytokines, which regulate MTOR activity chiefly via AKT, the TSC integrates other upstream signals to regulate via MTORC1. High AMP:ATP and/or ADP:ATP ratios lead to AMP and/or ADP binding to AMPK (Fig. 1). This leads to its activation, which is further potentiated by serine/ threonine kinase 11 (STK11) (Shaw et al. 2004b). AMPK phosphorylates TSC2, leading to its activation and the suppression of MTORC1 signaling (Inoki et al. 2006). AMPK can also be activated by glucose deprivation through an AMP/ATP-independent mechanism (Fig. 1), which is triggered by a glucose deprivation-induced decrease in fructose-1,6-bisphosphate levels and mediated by aldolase (Zhang et al. 2017).

Other signal transduction pathways converge on the TSC to exert their effects on MTORC1. For instance, the RAS-RAF-MEK-MAPK signaling pathway, which is activated by growth factors and frequently upregulated in cancer, can phosphorylate TSC2 directly or indirectly, via ribosomal protein S6 kinase A1 (RPS6A1), leading to stimulation of MTORC1 (Roux et al. 2004, Memmott \& Dennis 2009) (Fig. 1). In addition, studies have shown that DDIT4 (DNA damage inducible transcript 4) downregulates MTORC1 activity via TSC2 (Brugarolas et al. 2004, DeYoung et al. 2008) (Fig. 1). In response to hypoxia, DDIT4 mediated the dissociation of inhibitory 14-3-3 from the TSC2 protein so as to inhibit MTORC1 activity (DeYoung et al. 2008).
Overall, MTORC1 acts as an integrator of major regulatory inputs in the form of hypoxia, nutrients, energetic stress and growth factors, mostly via TSC.

Another important regulator of MTORC1 activity, the level of amino acids, is discussed in more detail in 'MTORC1 and the regulation of mRNA translation' section.

\section{MTORC1 and the regulation of MRNA translation}

mRNA translation occurs in four sequential steps: initiation, elongation, termination and ribosome recycling (Hershey et al. 2012). It is mainly regulated at the initiation phase, which is composed of two ratelimiting steps (Sonenberg \& Hinnebusch 2009). This includes (i) the formation of the $43 \mathrm{~S}$ pre-initiation complex (PIC) and (ii) the assembly of the EIF4F complex on the mRNA cap (Sonenberg \& Hinnebusch 2009). The initiation phase of mRNA cap-dependent translation involves the assembly of a 43S PIC, which comprises the eukaryotic initiation factors (EIFs) EIF1, EIF1A, EIF3 and EIF5, the $40 \mathrm{~S}$ ribosomal subunit and the ternary complex (TC). Furthermore, the TC comprises the EIF2 (containing alpha-, beta- and gamma-subunits), bound to GTP and tRNA $_{i}{ }^{\text {Met }}$ (Hinnebusch 2014). The EIF4F complex contains three subunits: EIF4E (mRNA cap-binding subunit), EIF4A (DEAD box RNA helicase) and EIF4G1 (scaffolding protein) (Fig. 2). The 43S PIC binds to the EIF4F complex via the interactions between EIF3 of the 43S PIC and EIF4G to create the 48S PIC (Hinnebusch 2014). The 43S PIC scans the 5' untranslated region (UTR) for the AUG start codon (Hinnebusch 2014). This is an ATP-dependent process that requires the helicase activity of EIF4A to unwind secondary structures present in the 5'UTR of mRNAs (Rogers et al. 1999). The recognition of the AUG start codon causes release of EIFs (Hinnebusch 2014). In addition, the $60 \mathrm{~S}$ ribosomal subunit joins the $40 \mathrm{~S}$ subunit to form the $80 \mathrm{~S}$ ribosome (Hinnebusch 2014). This process is facilitated by EIF5B-GTP hydrolysis (Hinnebusch 2014). Assembly of the 80 S ribosome marks the beginning of mRNA translation elongation.

During the elongation phase of mRNA translation, which is mediated by eukaryotic translation elongation factors (EEFs) (Mohr \& Sonenberg 2012), the mRNA codons dictate the sequence of specific tRNAs that go through the acylation-peptidyl-exit sites of ribosomes to form newly synthesized polypeptides (Jan et al. 2016). EEF1A (a G-protein), when bound to GTP, loads an amino-acyl charged tRNA into the A-site of the ribosome (Mohr \& Sonenberg 2012). The bound GTP is

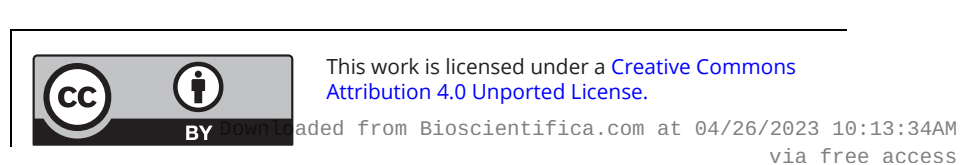




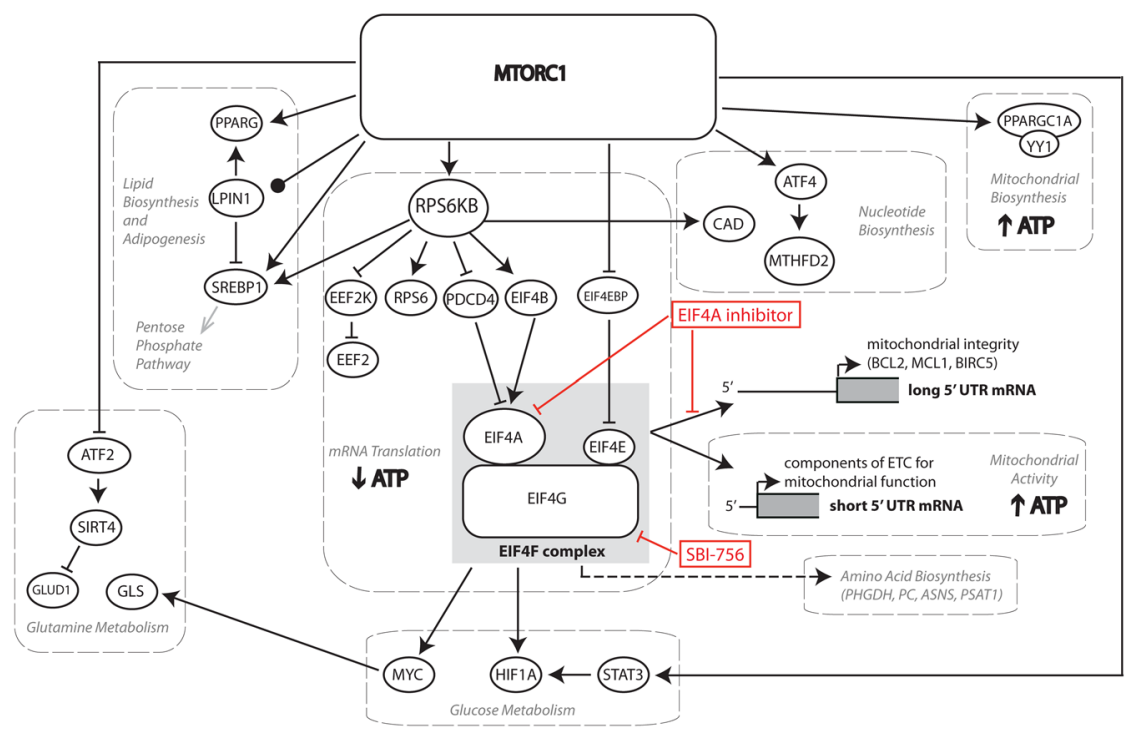

\section{Figure 2}

Schematic representation of effectors downstream of MTORC1. MTORC1 controls various metabolic processes via transcriptional and/or translational regulation. MTORC1 stimulates nucleotide synthesis (via ATF4), pentose phosphate pathway and lipid biosynthesis (via SREBP1), adipogenesis (via PPARG), glutamine metabolism (via ATF2 and MYC) and mitochondrial biogenesis (via PPARGC1A and YY1). The MTORC1/RPS6KB axis stimulates SREBP1 and CAD, which are essential for lipid and nucleotide biosynthesis, respectively. MTORC1 also stimulates lipid synthesis by controlling the nuclear localization of LPIN1, a negative regulator of SREBP1. In addition, MTORC1 phosphorylates LPIN1, facilitating its role as a coactivator for PPARG during adipogenesis. To date, the best characterized mediators of the effects of MTOR on protein synthesis are EIF4EBPs and RPS6KBs. MTOR stimulates the EIF4F complex assembly (comprised of EIF4E, EIF4G and EIF4A), by inactivating EIF4EBPs. In turn, RPS6KBs phosphorylate components of the translational machinery (PDCD4, RPS6, EIF4B and EEF2K). In respect to cancer energetics, the MTORC1/EIF4EBP/EIF4F axis regulates translation of mRNAs encoding mitochondrial factors (e.g. TFAM, ATP5O), central metabolic regulators (MYC and HIF1A) and enzymes involved in NEAA synthesis (PHGDH, PSAT1, PC and ASNS). The effects of EIF4A inhibitors and SBI-756 on MTOR-dependent translational and metabolic programs in explained within the text. ATF4, activating transcription factor 4; SREBP1, sterol regulatory element-binding transcription factor 1; PPARG, peroxisome proliferator-activated receptor gamma; ATF2, activating transcription factor 2; PPARGC1A, peroxisome proliferator-activated receptor gamma coactivator 1-alpha; YY1, Yin-Yang 1; RPS6KB, ribosomal protein S6 kinase; CAD, carbamoyl-phosphate synthetase 2, aspartate transcarbamylase, and dihydroorotase; LPIN1, lipin 1; EIF4EBP, eukaryotic initiation factor 4E-binding protein; EIF, eukaryotic initiation factor; PDCD4, programmed cell death 4; RPS6, ribosomal protein S6; EEF2K, eukaryotic elongation factor 2 kinase; TFAM, transcription factor A, mitochondrial; ATP5O, ATP synthase subunit O; HIF1A, hypoxia-inducible factor 1A; PRPS2, phosphoribosyl pyrophosphate synthetase 2; PHDH, phosphoglycerate dehydrogenase; PSAT1, phosphoserine aminotransferase1; PC, pyruvate carboxylase; ASNS, asparagine synthetase.

hydrolyzed when the anticodon of the incoming tRNA is matched against the corresponding mRNA codon (Agirrezabala \& Frank 2009). This process results in the formation of a peptide bond (Mohr \& Sonenberg 2012). The activity of EEF1A1 is regulated by EEF1B2 (a guanine exchange factor (GEF)) (Mohr \& Sonenberg 2012). EEF2 facilitates the translocation of the ribosome along the mRNA molecule (Taylor et al. 2007), leading to the uncharged tRNA molecule moving to the E-site and the freeing of the A-site (Starosta et al. 2014). The hydrolysis of another GTP molecule is required to catalyze the translocation of the ribosome (Stark et al. 2000). Elongation of the newly synthesized polypeptide continues until a stop codon is encountered on the mRNA molecule. For the termination step of mRNA translation, eukaryotic release factors (eRFs) recognize the stop codons, release the newly synthesized polypeptide and detach the $80 \mathrm{~S}$ ribosome from the mRNA transcript Printed in Great Britain
(Dever \& Green 2012). ETF1 (eukaryotic translation termination factor 1) mediates the hydrolysis of peptidyl-tRNA (Alkalaeva et al. 2006), in cooperation with GSPT1 (eRF3) (Alkalaeva et al. 2006). After this step, the mRNA and deacetylated tRNA are released and the ribosome dissociates into its subunits and is recycled (Kiel et al. 2007).

Malignant cells are characterized by their ability to proliferate uncontrollably, which correlates with their increased protein synthesis. The ability of cells to upregulate protein synthesis in response to increased physiological demands is in part mediated at the level of ribosome biogenesis (van Riggelen et al. 2010). Similar to protein synthesis, ribosome biogenesis is a complex multifactorial process that requires careful coordination and regulation. The role MTOR plays in regulating ribosome biogenesis has been extensively reviewed (Gentilella et al. 2015).

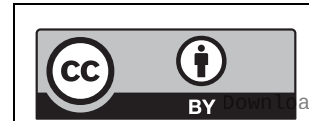

This work is licensed under a Creative Commons Attribution 4.0 Unported License. ded from Bioscientifica.com at 04/26/2023 10:13:34AM 
MTORC1 acts as a regulator of both translation initiation and elongation processes (Wang et al. 2001, Hsieh et al. 2012, Thoreen et al. 2012, Proud 2013). To date, eukaryotic translation initiation factors $4 \mathrm{E}$ binding proteins (EIF4EBP1-3 in mammals) and ribosomal protein S6 kinases (RPS6KB1 and RPS6KB2 in mammals) represent the best understood mediators of the effects of MTOR on protein synthesis (Fig. 2). MTORC1 phosphorylates EIF4EBPs (at Thr 37/Thr 46, followed by Thr 70 and finally Ser 65 in human EIF4EBP1) (Brunn et al. 1997, Gingras et al. 2001). Unphosphorylated EIF4EBPs sequester EIF4E and prevent its association with EIF4G1 (Fig. 2). Upon EIF4EBPs phosphorylation, EIF4E is released to form the active EIF4F complex (Sonenberg \& Hinnebusch 2009). In addition, MAPK (mitogen-activated protein kinase) interacting serine/threonine kinases (MKNKs) regulate mRNA translation through the phosphorylation of EIF4E residue on Ser209 (Waskiewicz et al. 1999). MKNK1 and MKNK2 phosphorylate EIF4E following MAPK14 and MAPK1/3 signaling pathways activation in response to cellular stress and mitogens, respectively (Flynn et al. 1997, Waskiewicz et al. 1997, Knauf et al. 2001). The EIF4F complex associates with MKNK1 via the carboxyl terminus of EIF4G (Pyronnet et al. 1999). The phosphorylation of EIF4E has been shown to affect EIF4E:mRNA cap association rates (Slepenkov et al. 2006). This suggests that EIF4E phosphorylation may affect the EIF4F complex assembly and/or binding of EIF4E to the mRNA cap (Scheper et al. 2002). Indeed, EIF4E phosphorylation increases the oncogenic potential of EIF4E (Topisirovic et al. 2004, Wendel et al. 2007) and is required for metastatic spread of the disease by selectively increasing translation of mRNAs encoding pro-survival (MCL1), pro-metastatic proteins (e.g. SNAIl (snail family transcriptional repressor 1), MMPs (matrix metallopeptidases)) and cytokines (Furic et al. 2010, Robichaud et al. 2015). Overall, EIF4F assembly is required for recruiting mRNAs to the ribosome, which is an essential step in initiating cap-dependent mRNA translation (Pause et al. 1994, Gingras et al. 1999).

MTORC1 also controls protein synthesis through the phosphorylation and activation of RPS6KBs (Roux \& Topisirovic 2012). Activated RPS6KBs phosphorylate ribosomal protein S6 (RPS6; a component of the 40S ribosomal subunit) (Banerjee et al. 1990), EIF4B (an auxiliary factor which stimulates EIF4A helicase) (Raught et al. 2004) and programmed cell death 4 (PDCD4; a negative regulator of the EIF4A function) (Holz et al. 2005, Dorrello et al. 2006, Chauvin et al. 2014) (Fig. 2).
Consequently, RPS6KBs indirectly increase EIF4A function in two ways: by activating its binding partner EIF4B and by phosphorylating and targeting for degradation its negative regulator PDCD4, to release it from the PDCD4-EIF4A complex (Dorrello et al. 2006, Dennis et al. 2012). In addition to mediating the effects of MTORC1 on translation initiation, RPS6KBs influence translation elongation. RPS6KBs phosphorylate and inactivate eukaryotic elongation factor 2 kinase (EEF2K), thereby preventing the phosphorylation and repression of its target EEF2 on the Thr56 residue. This facilitates translation elongation (Carlberg et al. 1990, Wang et al. 2001). EEF2K can also be directly phosphorylated by MTOR and AMPK (Browne \& Proud 2004, Browne et al. 2004). mRNA translation-related processes that are regulated by different signaling pathways have been recently reviewed in Roux and Topisirovic (2018).

Although the activation of MTORC1 correlates with increased global protein synthesis, it also leads to qualitative perturbations of the translatome (Meyuhas \& Dreazen 2009). MTORC1 preferentially enhances the translation of a subset of mRNAs bearing a series of 4-14 pyrimidines following the $\mathrm{C}$ nucleotide found immediately after the $5^{\prime}$ mRNA cap structure (Meyuhas \& Dreazen 2009). This motif is referred to as the $5^{\prime}$ terminal oligopyrimidine ( $5^{\prime}$ TOP) motif. The vast majority of TOP mRNAs encode components of the translational machinery such as ribosomal proteins, EEF2 and poly (A)-binding proteins (PABPs), and their translation is dramatically suppressed by MTOR inhibitors (Meyuhas \& Dreazen 2009, Hsieh et al. 2012). Initially, it was proposed that the RPS6KBs/RPS6 axis mediated the regulatory effects of MTOR on the translation of TOP mRNAs (Jefferies et al. 1994, 1997). Subsequently, it was however found that there was no difference in the translation of TOP mRNAs when cells deficient in RPS6KBs and expressing non-phosphorylable RPS6 (i.e. RPS6 knock-in) were compared to WT cells (Pende et al. 2004, Ruvinsky et al. 2005). In addition, although EIF4EBPs have been implicated in regulation of TOP mRNA translation (Thoreen et al. 2012), it has been shown that this is likely not the case in response to physiological stimuli (Miloslavski et al. 2014). Several additional factors recently emerged as potential mediators of MTORC1 signaling on the translation of TOP mRNA transcripts, such as La ribonucleoprotein domain family member 1 (LARP1) and TIA1/TIAL1 (Tcherkezian et al. 2014, Fonseca et al. 2015, Hong et al. 2017, Philippe et al. 2018). Furthermore, the context in which translation takes place is known to affect the translation of TOP mRNAs.

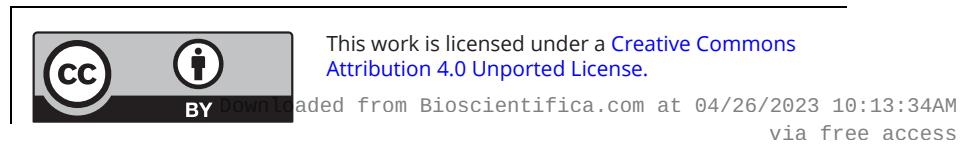


In addition to TOP mRNAs, other subsets of mRNAs have been shown to be affected by changes in MTOR activity (Larsson et al. 2012, Gandin et al. 2016). These mRNAs, commonly referred to as 'EIF4E sensitive', are highly dependent on EIF4E levels and/or availability. They mostly have long and highly structured, G/C-rich 5' UTRs and have a high requirement for the helicase activity of EIF4A, activity that is potentiated when EIF4A is present in the EIF4F complex (Koromilas et al. 1992, Svitkin et al. 2001, Silvera et al. 2010) (Fig. 2). Some of these mRNAs encode cell cycle regulators such as cyclins (cyclin D1 (CCND1)), pro-survival proteins (BCL2, MCL1, BCL2L1 (BCL2 like 1) and BIRC5), oncogenes (MYC, PIM1) and other proteins critical to cell proliferation (ornithine decarboxylase 1 (ODC1)) (De Benedetti \& Graff 2004, Mamane et al. 2004, Martelli et al. 2011, 2012). The translational regulation of these mRNAs is EIF4EBP dependent, underlying the major role of EIF4EBPs in meditating the effects of MTOR on cell proliferation (Dowling et al. 2010).

A subset of 'EIF4E-sensitive' mRNAs harbors very short 5'UTRs, which are enriched in TISU elements (Translation Initiator of Short 5' UTR; SAASATGGCGGC, in which $S$ is $C$ or G) (Elfakess et al. 2011). Many of the 'EIF4E-sensitive' genes with very short 5'UTR encode proteins involved in mitochondrial activity and biogenesis (discussed in more detail below) (Morita et al. 2013) (Fig. 2) and are less dependent on EIF4A activity (Gandin et al. 2016). This differentiates them from mRNAs with long 5' UTRs, encoding pro-proliferative and pro-survival proteins, which are both EIF4E and EIF4A sensitive (Gandin et al. 2016). As a consequence, the changes in the translational program induced by the inhibition of EIF4A differ from those induced by EIF4E inhibition and lead to a different metabolic and cell fate effect, which will be described in more detail in the following sections (Gandin et al. 2016).

\section{MTOR (MTORC1): master metabolic hub}

Malignant cells are characterized by uncontrolled cell proliferation and growth, which are made possible in part through translational and metabolic rewiring (Hanahan \& Weinberg 2011). In response to nutrients (glucose and amino acids), energetic requirements and growth factors (Inoki et al. 2003, Gwinn et al. 2008, Zoncu et al. 2011, Dibble et al. 2012, Efeyan et al. 2013), MTORC1 regulates different metabolic processes, such as the biosynthesis of proteins, lipids and nucleotides and autophagy (Holz et al. 2005, Duvel et al. 2010, Kim et al. 2011, Ben-Sahra et al. 2013).

\section{MTOR regulates glucose and glutamine metabolism}

MTORC1 stimulates glycolysis in part through the translational regulation of transcription factors such as MYC and hypoxia-inducible factor 1A (HIF1A) (Gordan et al. 2007, Duvel et al. 2010). In some cell types, MTORC1 regulates HIF1A translationally via EIF4EBP1 and RPS6KB1 (Dodd et al. 2015) (Fig. 2). MTORC1 also enhances the transcription of HIF1A mRNA by phosphorylating STAT3 (signal transducer and activator of transcription 3), which leads to HIF1A protein accumulation during hypoxia (Dodd et al. 2015).

HIF1A stimulates glucose flux and glycolysis through the activation of SLC2A1 (solute carrier family 2 member 1) transporter and of glycolytic proteins such as hexokinase, pyruvate kinase and phosphofructokinase (Semenza 2000, Wenger 2000, Keith et al. 2011). MYC has also been shown to upregulate the transcription of genes involved in glucose metabolism (Gordan et al. 2007, Stine et al. 2015). In fact, various proteins involved in glucose metabolism, such as lactate dehydrogenase (LDHA), phosphofructokinase, glucose transporter SLC2A1, hexokinase and PKM2 (pyruvate kinase M2) are both MYC and HIF1A targets (Shim et al. 1997, Osthus et al. 2000, Kim et al. 2007).

Glutamine is one of the most readily available nonessential amino acids used by malignant cells. It serves as an important source of energy, carbon and nitrogen for various anabolic reactions (Reitzer et al. 1979, Wise et al. 2008). Glutamine is the main contributor to the TCA cycle anaplerosis (replenishment of TCA cycle intermediates) (DeBerardinis et al. 2007), whereby TCA intermediates are used for lipid, nucleotide and amino acid synthesis (Wise \& Thompson 2010). Activated MTORC1 stimulates glutaminolysis, whereby glutamine is converted to glutamate by glutaminase (GLS) (Fig. 2) (Csibi et al. 2013). $\alpha$-Ketoglutarate, which is produced from glutamate by glutamate dehydrogenase (GLUD1), feeds into the TCA cycle (Csibi et al. 2013). One of the mechanisms by which MTORC1 promotes glutamine TCA anaplerosis is by indirectly inducing the transcriptional repression of SIRT4 (sirtuin 4), an inhibitor of GLUD1 activity, leading to GLUD1 activation (Csibi et al. 2013). This is achieved by MTORC1-mediated degradation of ATF2 (activating transcription factor 2), which is a transcription factor for SIRT4 (Csibi et al. 2013) (Fig. 2). Another mechanism by which MTORC1 activates TCA anaplerosis and affects glutamine metabolism is by positively regulating GLS levels through RPS6KB1-dependent regulation of MYC (Csibi et al. 2014). RPS6KB1 modulates the phosphorylation of EIF4B, which is necessary to the

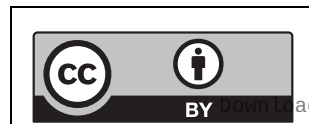

This work is licensed under a Creative Commons Attribution 4.0 Unported License. 
unwinding of the structured 5 ${ }^{\prime}$ UTR of MYC by EIF4A (Csibi et al. 2014) (Fig. 2).

In conclusion, MTORC1 modulates the uptake and/or metabolism of glucose and glutamine, the two main nutrients fueling cancer cells, through multiple mechanisms and layers of regulation.

\section{MTORC1 in regulating amino acids homeostasis}

Amino acids are not only required for protein synthesis but also serve as substrates for a variety of metabolic pathways and are major regulators of MTORC1 activity (Saxton \& Sabatini 2017). In mammals, heterodimeric RRAG (Ras-related GTP binding) GTPases regulate MTORC1 signaling in response to amino acid levels (Fig. 1) (Kim et al. 2008, Sancak et al. 2008). RRAGs form heterodimers of RRAGA or RRAGB in combination with RRAGC or RRAGD, respectively (Kim et al. 2008, Sancak et al. 2008). RRAG heterodimers associate with lysosomal membrane through their interaction with the Ragulator complex. The Ragulator complex, also known as LAMTOR (late endosomal/lysosomal adaptor, MAPK and MTOR activator), is composed of CDKN2C (cyclindependent kinase inhibitor 2C), CDKN2A (cyclindependent kinase inhibitor 2A), LAMTOR3, LAMTOR4 and LAMTOR5 (Sancak et al. 2010). LAMTOR acts as a GEF toward RRAGs (Sancak et al. 2010, Bar-Peled et al. 2012). The presence of amino acids stimulates RRAG heterodimers whereby RRAGC/D and RRAGA/B are GDP and GTP bound, respectively (Sancak et al. 2008) (Fig. 1). Active RRAG heterodimers recruit MTORC1 to the lysosomal surface via the interaction between the RRAGs and the MTORC1 subunit RPTOR (regulatory associated protein of MTOR complex 1), where MTORC1 becomes activated by RHEB (Bar-Peled et al. 2012). More recently, the mechanistic insights in the complexity of the control of MTORC1 activity by amino acids have been unraveled. For instance, the lysosomal v-ATPase interacts and stimulates the GEF activity of the LAMTOR complex in response to amino acids (Zoncu et al. 2011). Lysosomal amino acid transporter SLC38A9 has been implicated in interacting with the RRAG-LAMTOR-v-ATPase complex, which is necessary for arginine-dependent activation of MTORC1 (Jung et al. 2015). In addition, GATOR1 and GATOR2 complexes have been identified as regulators of MTORC1 signaling through their interaction with the RRAGs (Bar-Peled et al. 2013). The GATOR1 complex, which is composed of DEPDC5 (DEP domaincontaining 5), NPRL2 (NPR2 like) and NPRL3 (NPR3 like), is a negative regulator of MTORC1 (Bar-Peled et al. 2013).
It acts as a GAP for RRAGA/B (Bar-Peled et al. 2013). GATOR2 complex is composed of MIOS (meiosis regulator for oocyte development), WDR24 (WD repeat domain 24), WDR59, SEH1L (SEH1 like nucleoporin), and SEC13 and is a positive regulator of MTORC1 signaling (Bar-Peled et al. 2013). A newly identified complex called KICSTOR, which is composed of KPTN (kaptin, actin-binding protein), ITFG2 (integrin alpha FG-GAP repeat containing 2), C12orf66 (chromosome 12 open reading frame 66) and SZT2 has been shown to interact with GATOR1 on the lysosomal surface (Wolfson et al. 2017). The complex is important for sensing amino acid or glucose deprivation (Wolfson et al. 2017). In addition, cellular arginine sensor for MTORC1 (CASTOR1) has been shown to interact with GATOR2 and is necessary for arginine deprivation-induced downregulation of MTORC1 (Chantranupong et al. 2016). It is only recently that these different amino acids sensors were discovered and found to modulate the activities of MTORC1, opening the possibility for the existence of more amino acid sensors that may modulate MTORC1 via RRAGs.

In addition to being regulated by amino acid availability, MTORC1 is also involved in stimulating the synthesis of non-essential amino acids. Indirectly, MTOR regulates the synthesis of non-essential amino acids by stimulating glycolysis, TCA cycle and pentose phosphate pathways (Duvel et al. 2010, Yecies \& Manning 2011), which provide key metabolites necessary for amino acids synthesis (Duvel et al. 2010, Yecies \& Manning 2011) and regulating the translation of mRNAs encoding key enzymes involved in the synthesis of non-essential amino acids (Hulea et al., Cell Metabolism, in press; bioRxiv 160879; doi: https://doi.org/10.1101/160879).

Rapamycin, an allosteric inhibitor of MTORC1, causes acute MTORC1 inhibition by binding to FK506binding protein (FKBP), which interacts with MTOR and narrows its active site cleft (Harding et al. 1989, Siekierka et al. 1989, Yang et al. 2013). Rapamycin can also lead to MTORC2 inhibition after prolonged treatment, in certain cell lines and hepatocytes in vivo (Sarbassov et al. 2006, Lamming et al. 2012). Rapamycin has been shown to increase the expression of argininosuccinate synthase 1 (ASS1), which stimulates synthesis of arginine (Peng et al. 2002). Via MYC, MTORC1 indirectly regulates serine hydroxymethyltransferase 2 (SHMT2), involved in glycine synthesis (Nikiforov et al. 2002). Rapamycin-mediated MTOR inhibition also leads to a decrease in the levels of asparagine, which is linked to a decrease in expression of asparagine synthetase (ASNS) (Peng et al. 2002). Interestingly, it was proposed that asparagine functions as

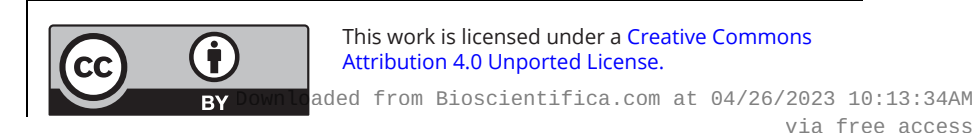


an amino acid exchange factor, regulating the uptake of amino acids (in particular serine, arginine and histidine) (Krall et al. 2016) and thus stimulating MTORC1 activity.

These findings add to the increasing amount of evidence highlighting the complexity of regulatory mechanisms whereby MTORC1 senses amino acids and regulates their utilization and synthesis.

\section{MTOR stimulates lipid synthesis}

Rapidly dividing malignant cells require increased synthesis of lipids, which are the main components of plasma and organelle membranes (Menendez \& Lupu 2007). MTORC1 regulates de novo lipid synthesis by relaying mitogenic and oncogenic signals to downstream effectors that are important for lipogenesis. Lipid biosynthesis is regulated by the sterol responsive elementbinding proteins (SREBF1 and SREBF2), which are activated by low sterol levels. SREBPs are transcription factors that regulate the expression of genes involved in the biosynthesis of fatty acids and sterols (Horton et al. 2002). MTORC1 activates SREBPs in a RPS6KB-dependent manner (Porstmann et al. 2008, Duvel et al. 2010, Li et al. 2016) (Fig. 2). Consistently, rapamycin downregulates the expression of SREBP gene targets including $A C L Y$, ACACA (acetyl CoA carboxylase alpha) and FASN (fatty acid synthase (Brown et al. 2007, Porstmann et al. 2008). MTORC2 inhibition has been shown to reduce the activity of SREBF1 and the expression of its target genes, such as ACACA and FASN, which suppresses lipogenesis (Li et al. 2016). The phosphatidic acid phosphatase LPIN1 has also been implicated in the regulation of lipid metabolism by MTORC1. In addition to its role in triglyceride synthesis, by converting phosphatidic acid to diacylglycerol, LPIN1 is a regulator of SREBF1 activity (Peterson et al. 2011). MTORC1 phosphorylates LPIN1, which prevents its translocation to the nucleus and thereby prevents the LPIN1-dependent suppression of SREBP activity (Peterson et al. 2011) (Fig. 2). Finally, MTOR can activate SREBF1 by phosphorylating CREB regulated transcription coactivator 2 (CRTC2) (Han et al. 2015), which attenuates CRTC2 inhibitory effects on the processing of SREBF1 (Han et al. 2015).

In addition to SREBPs, MTORC1 influences lipid metabolism by upregulating the activity of peroxisome proliferator-activated receptor gamma (PPARG) (Kim \& Chen 2004) (Fig. 2). Hyperactivation of the MTORC1 pathway stimulates PPARG-dependent adipogenesis (Zhang et al. 2009), while rapamycin leads to the reduction of both mRNA and protein levels of PPARG and the inhibition of adipogenesis (Cho et al. 2004, Kim \& Chen 2004). There is evidence showing that MTORC1 mediates its effects on the regulation of PPARG via EIF4EBPs and RPS6KB1 (Um et al. 2004, Le Bacquer et al. 2007). Disruption of EIF4EBP1 and EIF4EBP2 in mice led to increased sensitivity to diet-induced obesity driven by increased expression of CCAAT/enhancer-binding proteins (CEBPD, CEBPA) and PPARG (Le Bacquer et al. 2007). This was associated with reduced energy expenditure, reduced lipolysis and greater fatty acid re-esterification in the adipose tissue (Le Bacquer et al. 2007). Furthermore, resistance to insulin in EIF4EBP1 and EIF4EBP2 double knockout mice was associated with increased RPS6KB activity, which impaired AKT signaling in muscle, liver and adipose tissue. LPIN1 also plays a role in the regulation of PPARG, acting as its transcriptional coactivator (Koh et al. 2008) (Fig. 2). On the basis of these findings, MTORC1 regulates lipid synthesis chiefly by perturbing activity of SREBPs and PPARG.

\section{MTOR and the regulation of PPP and nucleotide synthesis}

Pentose phosphate pathway (PPP) is required to generate ribose 5-phosphate from glucose and regenerate NADPH via its oxidative arm (Horecker et al. 1951, Glaser \& Brown 1955, Dickens \& Williamson 1956). NADPH is an important reducing equivalent necessary to fuel various metabolic reactions including lipid biosynthesis and plays an important role in protection from oxidative damage (Oudejans et al. 1983, Winkler et al. 1986). Ribose 5-phosphate, which is converted to 5'-phosphoribosyl-1'pyrophosphate, is an essential precursor for nucleotide synthesis (Hove-Jensen 1989). MTORC1 has been shown to regulate expression of PPP genes partly through SREBPs (Fig. 2) (Duvel et al. 2010), while PI3K inhibition has been shown to inhibit the PPP (Wang et al. 2009).

The MTORC1/RPS6KB1 signaling axis stimulates de novo pyrimidine synthesis via the phosphorylation of glutamine-dependent carbamoyl-phosphate synthetase 2, aspartate transcarbamylase and dihydroorotase (CAD) (Ben-Sahra et al. 2013, Robitaille et al. 2013) (Fig. 2). This enzyme mediates the formation of the pyrimidine ring (Ben-Sahra et al. 2013, Robitaille et al. 2013). In addition, MTORC1 transcriptionally regulates multiple enzymes involved in purine synthesis via the ATF4-dependent expression of methylenetetrahydrofolate dehydrogenase 2 (MTHFD2) (Ben-Sahra et al. 2016) (Fig. 2). MTHFD2 is an essential enzyme for the mitochondrial tetrahydrofolate cycle, which provides one-carbon units 
for purine synthesis (Shuvalov et al. 2017). Finally, in MYC-transformed cells, phosphoribosyl pyrophosphate synthetase 2 (PRPS2) mRNA is translationally regulated in an EIF4E-dependent manner, leading to increased nucleotide biosynthesis (Cunningham et al. 2014).

By regulating nucleotide synthesis, MTORC1 provides the building blocks for RNA and DNA synthesis, needed for ribosome biogenesis, cellular growth and proliferation.

\section{The role of MTOR in the regulation of mitochondrial biogenesis and activity}

Considering that mRNA translation is a highly energyconsuming cellular process, it is closely coordinated with cellular energy production (Topisirovic \& Sonenberg 2011). To this end, malignant cells must meet the heightened energy requirement caused by elevated energy consumption by the protein synthesis apparatus (Ward \& Thompson 2012, Ruggero 2013). It has been reported that MTORC1 activity is positively correlated with ATP production (Morita et al. 2013). Rapamycin reduces oxygen consumption and ATP synthetic capacity (Schieke et al. 2006). MTORC1 regulates energy production in the mitochondria in a EIF4EBP1-dependent manner, by regulating the translation of nuclear-encoded mitochondria-related mRNAs such as components of complex I and V, mitochondrial ribosomal proteins and transcription factor a, mitochondrial (TFAM) (Fig. 2) (Morita et al. 2013). The vast majority of these proteins are encoded by mRNAs harboring short 5'UTR/TISU elements (Gandin et al. 2016), and their translation is EIF4E sensitive, but not affected by EIF4A inhibition, as previously discussed (Roux et al. 2004) (Fig. 2). Finally, the MTORC1/EIF4EBP axis has been shown to regulate mitochondrial dynamics by modulating translation of mitochondrial fission process 1 (MTFP1) (Morita et al. 2017).

In addition to translational regulation, MTORC1 regulates the transcription of mitochondrial genes via PPARG coactivator 1 alpha (PPARGC1A) (Fig. 2) (Cunningham et al. 2007). The inhibition of MTORC1 by rapamycin decreased the expression of mitochondrial transcriptional regulators PPARGC1A, estrogen-related receptor alpha (ESRRA) and nuclear respiratory factors, which resulted in reduced mitochondrial gene expression and oxygen consumption (Cunningham et al. 2007). Further analysis identified the transcription factor Yin-Yang 1 (YY1) as the common target of MTOR and PPARGC1A that is required for rapamycin-dependent repression of those genes (Fig. 2) (Cunningham et al. 2007).
Future work is required to establish the coordination of MTORC1-dependent translational and transcriptional programs that govern mitochondrial biogenesis and functions. MTORC2 was also shown to be important for maintaining mitochondria associated ER membrane integrity (Betz et al. 2013). MTORC2 deficiency causes increases in mitochondrial membrane potential, ATP production and calcium uptake (Betz et al. 2013).

\section{Nuclear activity of MTOR}

In addition to the previously discussed roles of MTOR in regulating translation, it has emerged that MTOR can directly influence the transcription of metabolic genes of prostate cancer cells via its interaction with androgen receptor in the nucleus (Audet-Walsh et al. 2017). Interestingly, in castration-resistant prostate cancer cells, MTOR transcriptional activity and modulation of metabolic programs occurred even in the absence of androgens (Audet-Walsh et al. 2017). These results bring forward the importance of nuclear MTOR and the need for additional work to uncover its role in this cellular compartment.

\section{Role of MTORC2 in metabolic regulation}

MTORC2 is known to regulate cell survival, metabolism, cytoskeletal organization and cell migration (Oh \& Jacinto 2011, Populo et al. 2012, Soukas et al. 2009). MTORC2 also regulates metabolic processes such as glycolysis, glutaminolysis, lipogenesis and nucleotide metabolism (Masui et al. 2014). Abrogation of MTORC2 in the liver impaired glycolysis and lipogenesis and led to constitutive gluconeogenesis (Hagiwara et al. 2012). Consequentially, this led to systemic hyperglycemia, hyperinsulinemia, and hypolipidemia (Hagiwara et al. 2012). In addition, MTORC2 in adipose tissue appears to systemically affect whole-body growth (Cybulski et al. 2009). MTORC2 has been shown to regulate glycolysis and glutaminolysis indirectly by regulating MYC levels through FOXO1 and FOXO3 acetylation (Masui et al. 2013). However, compared to MTORC1, the role of MTORC2 in metabolic regulation is largely understudied.

\section{Therapeutic implications of the cross-talk between translatome and metabolome}

The hypothesis that drugs can exploit cancer specific metabolic vulnerabilities (Vander Heiden et al. 2009) is attractive. Since protein synthesis, which is the most energy consuming process in the cell, is also dysregulated

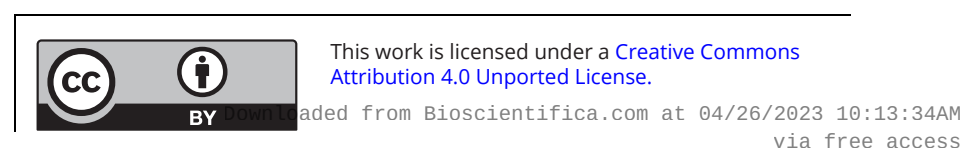


in cancer, targeting the translational machinery has also been considered to increase the efficacy of anti-cancer treatments (Hagner et al. 2010).

Since MTORC1 acts as a pivotal regulator of major metabolic pathways and protein synthesis, targeting MTORC1 represents an appealing strategy to simultaneously target translational apparatus and cancer energetics. By inhibiting MTORC1, rapamycin induces changes in cellular metabolism, including decrease in mitochondrial activity, amino acid biosynthesis, PPP and sterol and lipid biosynthesis (Peng et al. 2002, Schieke et al. 2006, Cunningham et al. 2007, Ramanathan \& Schreiber 2009, Duvel et al. 2010). At the organismal level, rapamycin treatment results in hyperglycemia, hyperlipidemia, a decrease in glucose-stimulated insulin synthesis and secretion and weight loss (Fraenkel et al. 2008). Overall, rapamycin suppresses key metabolic processes by inhibiting MTORC1.

Rapamycin and its analogs (rapalogs; Fig. 1) are FDA approved for the treatment of renal cell carcinomas, mantle cell lymphomas and pancreatic neuroendocrine tumors (Li et al. 2014a). However, the efficacy in the clinic is not as good as initially hoped (Fasolo \& Sessa 2008). This can been justified in part by the activation of AKT via the suppression of the RPS6KB1-IRS1-PI3K-AKT regulatory feedback, as well as by rapamycin's inability to inhibit certain MTORC1 outputs including phosphorylation of EIF4EBPs (Dowling et al. 2010, Faes et al. 2017). To this end, more efficient means to target MTOR were developed, including active site MTOR inhibitors (asTORi), which target ATP-binding pocket of MTOR, and third-generation MTOR inhibitors (RapaLink-1), which combine allosteric and active site inhibition (Benjamin et al. 2011, Roux \& Topisirovic 2012, Rodrik-Outmezguine et al. 2016) (Fig. 1). The new generation of MTOR inhibitors efficiently suppress EIF4EBP phosphorylation and reduce AKT signaling via inhibition of MTORC2 (Benjamin et al. 2011). These inhibitors are presently under investigation in clinical trials and are expected to exhibit enhanced efficacy in the clinic as compared to rapalogs.

In addition to MTOR inhibitors, the vast majority of oncogenic kinase inhibitors indirectly suppress MTORC1 and are thus positioned to alter the cross-talk between translational machinery and energy metabolism in neoplasia. Lapatinib is a dual receptor tyrosine kinase inhibitor (TKI) (Fig. 1) of epidermal growth factor receptor (EGFR) and ERB-B2 resceptor Tyrosine kinase (EEEB2) human epidermal growth factor receptor 2 (HER2), which is used for treating HER2-positive breast cancer (Geyer et al. 2006). Lapatinib inhibits the RAS-RAF-MEK-MAPK and MTORC1 signaling pathways (Brady et al. 2015). Furthermore, lapatinib inhibits glycolysis and reduces mitochondrial membrane potential (Paech et al. 2017). Vemurafenib is a BRAF V600E serine/threonine kinase inhibitor used in the treatment of advanced melanoma (Young et al. 2012). It downregulates the RAS-RAF-MEKMAPK and MTORC1 signaling pathways (Zhan et al. 2015) (Fig. 1). Similar to lapatinib, vemurafenib inhibits glycolysis in melanoma cells (Delgado-Goni et al. 2016). Furthermore, vemurafenib increases oxidative and anaplerotic pyruvate carboxylase (PC) mitochondrial metabolism and decreases lipid synthesis (DelgadoGoni et al. 2016). Imatinib is another TKI that suppresses abnormal activation of the PI3K/AKT/MTORC1 pathway downstream of a constitutively active BCR/ABL kinase present in chronic myelogenous leukemia (Hirao et al. 2018). Consistent with most kinase inhibitors (KI), imatinib also inhibits glucose uptake and glycolysis (Boren et al. 2001, Gottschalk et al. 2004). Moreover, its ability to alter metabolic enzyme activities involved in fatty acid and de novo nucleic acid synthesis demonstrates the mechanism by which it inhibits leukemia cell growth (Boren et al. 2001).

While KI suppress MTOR signaling, their inability to impede EIF4F complex assembly dramatically reduces their anti-neoplastic efficacy. For example, in BRAF(V600)-mutated melanoma, resistance to antiBRAF and anti-MEK therapies, can be overturned by altering EIF4F complex activity by using EIF4A inhibitors (Boussemart et al. 2014). In a model of mammary epithelial cells, resistance to PI3K/MTOR inhibitor BEZ235 was induced by either MYC or EIF4E amplification (Ilic et al. 2011). Resistant cells showed elevated 5' cap-dependent mRNA translation, supporting the importance of EIF4F activity in development of resistance to KI (Ilic et al. 2011). In breast cancer xenografts, overexpressing EIF4E induces resistance to ERBB2 and EGFR inhibitors including lapatinib (Zindy et al. 2011). Similarly, high EIF4F and cap-dependent translation levels occur in nonsmall cell lung cancer cells resistant to EGFR inhibitor erlotinib (Patel et al. 2013). More generally, a high EIF4E/EIF4EBP ratio was shown to dramatically decrease the efficacy of MTOR inhibitors across multiple cancer cell lines and in vivo (Alain et al. $2012 a, b)$. Overall, these findings underscore the role of translation machinery in determining the efficacy of MTOR targeted therapies and suggest that the inability of such approaches to suppress mRNA translation may facilitate metabolic adaptations of cancer cells to KIs.

This work is licensed under a Creative Commons Attribution 4.0 Unported License. 
Combinations of KI that impinge on EIF4F (e.g. MTOR inhibitors) with oncogenic KI (e.g. TKIs) have been explored. The BOLERO-3 clinical trial has tested a combination of everolimus, a rapalog, and trastuzumab, which targets the ERBB2 receptor (Andre et al. 2014). Based on the initial results of the BOLOERO-3 trial, it appears that such combination represents a promising therapeutic strategy to target patients with advanced ERBB2+ breast cancer developing resistance to conventional therapy (Andre et al. 2014). However, in a subset of patients, high EIF4E/EIF4EBP ratio may result in resistance to trastuzumab/everolimus combinations (Alain et al. 2012a). Notably, alternative possibilities of targeting the translation machinery have been developed (e.g. EIF4A inhibitors). These therapies target directly the formation of the EIF4F complex and could provide good candidates for combination with KI to manage resistance. They are discussed in more detail in the next section.

\section{Cancer metabolism and therapeutic implications}

Although metabolic reprograming in cancer is thought to provide sufficient therapeutic window to selectively target malignant cells, while not causing excessive toxicity in normal tissues, changes in metabolic and associated translational programs are also linked to the development of drug resistance (Zhao et al. 2010, Han et al. 2015, Deblois et al. 2016). For example, sustained MTOR activation observed in SKBr3 lapatinib-resistant cells, leads to dysregulated expression of ESSRA, which mediates lapatinib resistance through increased glutamine metabolism and ROS detoxification (Deblois et al. 2016). Moreover, ESRRA mediates the intrinsic resistance of breast cancer cells to PI3K/MTOR inhibitors (Park et al. 2016). ESRRA regulates the expression of genes that allow utilization of lactate as an energy source, which enables breast cancer cells to adapt to extended periods of glucose deprivation (Park et al. 2016). Vemurafenibresistant cells have been shown to reactivate their MAPK signaling pathway and/or to have high MTOR and EIF4F activity (Poulikakos et al. 2011, Boussemart et al. 2014). These cells also uptake glutamine at a faster rate compared to non-resistant cells (Hernandez-Davies et al. 2015). In addition, vemurafenib resistance induces an oxidative phosphorylation gene program, mitochondrial biogenesis, and increase expression of PPARGC1A (Han et al. 2015). Imatinib-resistant chronic myelogenous leukemia cells have been shown to have increased glycolytic rate and HIF1A-dependent activation of the non-oxidative PPP transketolase enzyme (Zhao et al. 2010). Hence, metabolic reprogramming at least in part mediates the resistance of malignant cells to KI, which is further exacerbated by the seemingly outstandingly plasticity of malignant metabolomes.

Strategies to overcome metabolic adaptations of cancer cells to KI, whereby combinatory drugs are used to disrupt metabolic reprogramming processes which underpin development of resistance, are being developed. For example, the inhibition of ESRRA with compound C29, used in combination with lapatinib, may be effective in treating lapatinib-resistant cells (Deblois et al. 2016). This is because C29 impedes the ESRRA-mediated glutamine addiction that results from lapatinib treatment (Deblois et al. 2016). Metformin is a biguanide drug which is commonly used for treatment of type 2 diabetes (Pollak 2010). Biguanides (Fig. 1) induce energetic stress by reducing oxidative phosphorylation through the partial inhibition of complex I of the mitochondrial respiratory chain (Andrzejewski et al. 2014, Bridges et al. 2014, Wheaton et al.2014). This leads to increased glucose uptake and elevated dependence on glycolysis (Javeshghani $e t$ al. 2012). Hence, there is a rationale for combining BRAF inhibitors (BRAFi), which suppress glycolysis, and biguanides (Zhao et al. 2010). Indeed, phenformin - a more potent inhibitor of mitochondrial complex I - and BRAF inhibitors exhibits synergistic anti-tumorigenic effects in melanoma (Yuan et al. 2013, Bridges et al. 2014). Furthermore, BRAFi resistant melanoma cells have an increased reliance on glutaminolysis, as they were shown to be more sensitive to glutamine starvation and glutaminase inhibitors compared to BRAFi-sensitive cells (Hernandez-Davies et al. 2015, Baenke et al. 2016). These examples suggest that using drug combinations that alter metabolic adaptations which underlie resistance to KIs may constitute an effective therapeutic strategy.

Consistently, combination of phenformin with various KI (lapatinib, vemurafenib, imatinib) results in synergistic anti-proliferative effects, which are paralleled by MTORC1 inhibition, disruption of the EIF4F complex and the downregulation of the translational control of genes involved in non-essential amino acid synthesis (NEAA) (serine, aspartate, asparagine): phosphoglycerate dehydrogenase (PHGDH), phosphoserine aminotransferase 1 (PSAT1), PC and ASNS (Hulea et al., Cell Metabolism, in press; bioRxiv 160879; doi: https:// doi.org/10.1101/160879) (Fig. 2). However, cells lacking EIF4EBP1 and EIF4EBP2, in which MTORC1 inhibition is uncoupled from EIF4F disassembly, show dramatically reduced sensitivity to the phenformin/KI combinations

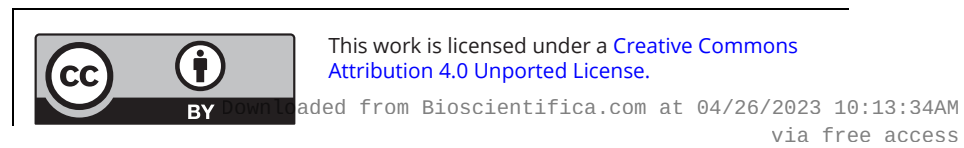


enzymes (Hulea et al., Cell Metabolism, in press; bioRxiv 160879; doi: https://doi.org/10.1101/160879). This at least in part is a consequence of their inability to suppress NEAA biosynthesis and translation of mRNAs encoding corresponding enzymes (Hulea et al., Cell Metabolism, in press; bioRxiv 160879; doi: https:// doi.org/10.1101/160879). A similar phenomenon was observed in cells depleted of von Hippel-Lindau (VHL) tumor suppressor, the major regulator of HIF1A protein stability (Semenza 2007). VHL-null cells maintain high HIF1A protein levels under normoxic conditions (Maxwell et al. 1999) and are less sensitive to the phenformin/KI combinations, at least in part due to changes in the glutamine metabolic program in these cells (Hulea et al., Cell Metabolism, in press; bioRxiv 160879; doi: https://doi.org/10.1101/160879). Collectively, these findings emphasize the plasticity of translational and metabolic programs of cancer cells, which allows them to rapidly adapt to therapeutic insults.

One way of circumventing the problems associated with plasticity of cancer cells may be a direct targeting of the EIF4F complex. EIF4A inhibitors (EIF4Ai), but not MTOR inhibitors, lead to specific translational reprogramming, which results in mitochondrial depolarization and cancer cell death (Gandin et al. 2016) (Fig. 2). The cytotoxic effect of EIF4Ai is noteworthy, as the effect of MTOR inhibitors on cancer cells is cytostatic (Gandin et al. 2016). The cytostatic effect of MTOR inhibition can be explained by modification in the translational program that reduce both energy production and energy utilization (Morita et al. 2013), leading to metabolic dormancy. These studies highlight the superiority of EIF4Ai and other drugs directly affecting the EIF4F complex formation and, in light of what has been discussed above, warrant additional effort into better understanding their effects on cancer cell metabolism. SBI-756 is a compound which was shown to bind to EIF4G1 and disrupt the EIF4F complex independently of the MTOR/EIF4EBP axis (Feng et al. 2015). Most importantly, SBI-756 eradicated BRAFinhibitor resistant melanoma cells, as well as EIF4EBP null cancer cells, which are resistant to MTOR inhibitors (Feng et al. 2015).

In the context of combination therapy with drugs inducing energetic stress, therapies resulting in reduced energy consumption, leading to metabolic dormancy and a cytostatic effect, are not very effective. Therefore, in order to effectively kill cancer cells by inducing energetic stress, the ideal drug combination would be one that on one hand reduces energy production, and on the other hand affects dysregulated oncogenic signal while maintaining energy consumption (e.g. by carrying specific translational reprogramming without greatly affecting global translation levels).

\section{Future perspectives}

Although significant efforts have been made to therapeutically target cancer metabolism, progress remains limited. It is becoming apparent that intratumor heterogeneity severely hinders the success of therapeutic efforts aiming to target metabolic vulnerabilities. It is likely impossible to develop effective treatments that eliminate the dozens of aberrant signaling pathways that are present within a single resistant tumor. However, considering that the abnormal regulation of mRNA translation, resulting in metabolic reprogramming, is a 'final common pathway' downstream of driver mutations, we can assume that therapies that restrain abnormal translation may have utility independent of the nature of upstream drivers. Of particular interest would be the opportunities for synthetic lethality whereby one drug induces a metabolic stress while the other impedes adaptation of cancer cells to that stress. Further research is thus warranted to grasp the full complexity and plasticity of cancer metabolomes.

\section{Declaration of interest}

The authors declare that there is no conflict of interest that could be perceived as prejudicing the impartiality of this review.

\section{Funding}

I T is supported by Junior 2 FRQ-S award and research in our lab pertinent to this review is funded by grants Canadian Cancer Society Research Institute (CCSRI-703816) to I T and M P, Canadian Institutes for Health Research (MOP-363027) to I T, and Terry Fox Research Institute (TFF-116128) to I T and $\mathrm{M} P$.

\section{Acknowledgments}

The authors thank Shannon McLaughlan for the administrative support and Kristofferson Tandoc for the critical reading of the manuscript.

\section{References}

Accili D \& Arden KC 2004 FoxOs at the crossroads of cellular metabolism, differentiation, and transformation. Cell 117 421-426. (https://doi.org/10.1016/S0092-8674(04)00452-0)

Agirrezabala X \& Frank J 2009 Elongation in translation as a dynamic interaction among the ribosome, tRNA, and elongation factors EF-G and EF-Tu. Quarterly Reviews of Biophysics 42 159-200. (https://doi. org/10.1017/S0033583509990060)

Alain T, Morita M, Fonseca BD, Yanagiya A, Siddiqui N, Bhat M, Zammit D, Marcus V, Metrakos P, Voyer LA, et al. 2012a eIF4E/4E-BP

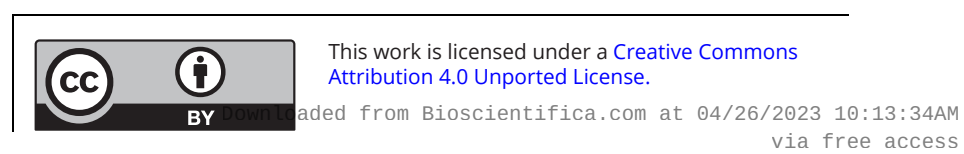


ratio predicts the efficacy of mTOR targeted therapies. Cancer Research 72 6468-6476. (https://doi.org/10.1158/0008-5472.CAN-122395)

Alain T, Sonenberg N \& Topisirovic I $2012 b$ mTOR inhibitor efficacy is determined by the eIF4E/4E-BP ratio. Oncotarget 3 1491-1492.

Alessi DR, James SR, Downes CP, Holmes AB, Gaffney PR, Reese CB \& Cohen P 1997 Characterization of a 3-phosphoinositide-dependent protein kinase which phosphorylates and activates protein kinase Balpha. Current Biology 7 261-269. (https://doi.org/10.1016/S09609822(06)00122-9)

Alkalaeva EZ, Pisarev AV, Frolova LY, Kisselev LL \& Pestova TV 2006 In vitro reconstitution of eukaryotic translation reveals cooperativity between release factors eRF1 and eRF3. Cell 125 1125-1136. (https:// doi.org/10.1016/j.cell.2006.04.035)

Andre F, O'Regan R, Ozguroglu M, Toi M, Xu B, Jerusalem G, Masuda N, Wilks S, Arena F, Isaacs C, et al. 2014 Everolimus for women with trastuzumab-resistant, HER2-positive, advanced breast cancer (BOLERO-3): a randomised, double-blind, placebo-controlled phase 3 trial. Lancet Oncology 15 580-591. (https://doi.org/10.1016/S14702045(14)70138-X)

Andrzejewski S, Gravel SP, Pollak M \& St-Pierre J 2014 Metformin directly acts on mitochondria to alter cellular bioenergetics. Cancer Metabolism 2 12. (https://doi.org/10.1186/2049-3002-2-12)

Audet-Walsh E, Dufour CR, Yee T, Zouanat FZ, Yan M, Kalloghlian G, Vernier M, Caron M, Bourque G, Scarlata E, et al. 2017 Nuclear mTOR acts as a transcriptional integrator of the androgen signaling pathway in prostate cancer. Genes and Development 31 1228-1242. (https://doi.org/10.1101/gad.299958.117)

Baenke F, Chaneton B, Smith M, Van Den Broek N, Hogan K, Tang H, Viros A, Martin M, Galbraith L, Girotti MR, et al. 2016 Resistance to BRAF inhibitors induces glutamine dependency in melanoma cells. Molecular Oncology 10 73-84. (https://doi.org/10.1016/j. molonc.2015.08.003)

Banerjee P, Ahmad MF, Grove JR, Kozlosky C, Price DJ \& Avruch J 1990 Molecular structure of a major insulin/mitogen-activated 70-kDa S6 protein kinase. PNAS 87 8550-8554. (https://doi.org/10.1073/ pnas.87.21.8550)

Bar-Peled L, Schweitzer LD, Zoncu R \& Sabatini DM 2012 Ragulator is a GEF for the rag GTPases that signal amino acid levels to mTORC1. Cell 150 1196-1208. (https://doi.org/10.1016/j.cell.2012.07.032)

Bar-Peled L, Chantranupong L, Cherniack AD, Chen WW, Ottina KA, Grabiner BC, Spear ED, Carter SL, Meyerson M \& Sabatini DM 2013 A tumor suppressor complex with GAP activity for the Rag GTPases that signal amino acid sufficiency to mTORC1. Science $\mathbf{3 4 0}$ 1100-1106. (https://doi.org/10.1126/science.1232044)

Ben-Sahra I, Howell JJ, Asara JM \& Manning BD 2013 Stimulation of de novo pyrimidine synthesis by growth signaling through mTOR and S6K1. Science 339 1323-1328. (https://doi.org/10.1126/ science.1228792)

Ben-Sahra I, Hoxhaj G, Ricoult SJH, Asara JM \& Manning BD 2016 mTORC1 induces purine synthesis through control of the mitochondrial tetrahydrofolate cycle. Science 351 728-733. (https:// doi.org/10.1126/science.aad0489)

Benjamin D, Colombi M, Moroni C \& Hall MN 2011 Rapamycin passes the torch: a new generation of mTOR inhibitors. Nature Reviews Drug Discovery 10 868-880. (https://doi.org/10.1038/nrd3531)

Berwick DC, Hers I, Heesom KJ, Moule SK \& Tavare JM 2002 The identification of ATP-citrate lyase as a protein kinase B (Akt) substrate in primary adipocytes. Journal of Biological Chemistry $\mathbf{2 7 7}$ 33895-33900. (https://doi.org/10.1074/jbc.M204681200)

Betz C, Stracka D, Prescianotto-Baschong C, Frieden M, Demaurex N \& Hall MN 2013 Feature Article: mTOR complex 2-Akt signaling at mitochondria-associated endoplasmic reticulum membranes (MAM) regulates mitochondrial physiology. PNAS 110 12526-12534. (https://doi.org/10.1073/pnas.1302455110)
Boren J, Cascante M, Marin S, Comin-Anduix B, Centelles JJ, Lim S, Bassilian S, Ahmed S, Lee WN \& Boros LG 2001 Gleevec (STI571) influences metabolic enzyme activities and glucose carbon flow toward nucleic acid and fatty acid synthesis in myeloid tumor cells. Journal of Biological Chemistry 276 37747-37753.

Boussemart L, Malka-Mahieu H, Girault I, Allard D, Hemmingsson O, Tomasic G, Thomas M, Basmadjian C, Ribeiro N, Thuaud F, et al. 2014 eIF4F is a nexus of resistance to anti-BRAF and anti-MEK cancer therapies. Nature 513 105-109. (https://doi.org/10.1038/ nature13572)

Brady SW, Zhang J, Tsai MH \& Yu D 2015 PI3K-independent mTOR activation promotes lapatinib resistance and IAP expression that can be effectively reversed by mTOR and Hsp90 inhibition. Cancer Biology and Therapy 16 402-411. (https://doi.org/10.1080/15384047.2 014.1002693)

Bridges HR, Jones AJ, Pollak MN \& Hirst J 2014 Effects of metformin and other biguanides on oxidative phosphorylation in mitochondria. Biochemical Journal 462 475-487. (https://doi.org/10.1042/ BJ20140620)

Brown NF, Stefanovic-Racic M, Sipula IJ \& Perdomo G 2007 The mammalian target of rapamycin regulates lipid metabolism in primary cultures of rat hepatocytes. Metabolism 56 1500-1507. (https://doi.org/10.1016/j.metabol.2007.06.016)

Browne GJ \& Proud CG 2004 A novel mTOR-regulated phosphorylation site in elongation factor 2 kinase modulates the activity of the kinase and its binding to calmodulin. Molecular and Cellular Biology 24 2986-2997. (https://doi.org/10.1128/МСB.24.7.2986-2997.2004)

Browne GJ, Finn SG \& Proud CG 2004 Stimulation of the AMP-activated protein kinase leads to activation of eukaryotic elongation factor 2 kinase and to its phosphorylation at a novel site, serine 398. Journal of Biological Chemistry 279 12220-12231. (https://doi.org/10.1074/ jbc.M309773200)

Brugarolas J, Lei K, Hurley RL, Manning BD, Reiling JH, Hafen E, Witters LA, Ellisen LW \& Kaelin WG Jr 2004 Regulation of mTOR function in response to hypoxia by REDD1 and the TSC1/TSC2 tumor suppressor complex. Genes and Development 18 2893-2904. (https://doi.org/10.1101/gad.1256804)

Brunn GJ, Hudson CC, Sekulic A, Williams JM, Hosoi H, Houghton PJ, Lawrence JC Jr \& Abraham RT 1997 Phosphorylation of the translational repressor PHAS-I by the mammalian target of rapamycin. Science 277 99-101. (https://doi.org/10.1126/ science.277.5322.99)

Buttgereit F \& Brand MD 1995 A hierarchy of ATP-consuming processes in mammalian cells. Biochemical Journal 312 163-167. (https://doi. org/10.1042/bj3120163)

Byrnes KW, DeBenedetti A, Holm NT, Luke J, Nunez J, Chu QD, Meschonat C, Abreo F, Johnson LW \& Li BD 2007 Correlation of TLK1B in elevation and recurrence in doxorubicin-treated breast cancer patients with high eIF4E overexpression. Journal of the American College of Surgeons 204 925-933; discussion 933-924. (https://doi.org/10.1016/j.jamcollsurg.2007.02.027)

Cantley LC 2002 The phosphoinositide 3-kinase pathway. Science 296 1655-1657. (https://doi.org/10.1126/science.296.5573.1655)

Carlberg U, Nilsson A \& Nygard O 1990 Functional properties of phosphorylated elongation factor 2. European Journal of Biochemistry 191 639-645. (https://doi.org/10.1111/j.1432-1033.1990.tb19169.x)

Chang CH, Qiu J, O'Sullivan D, Buck MD, Noguchi T, Curtis JD, Chen Q, Gindin M, Gubin MM, van der Windt GJ, et al. 2015 Metabolic competition in the tumor microenvironment is a driver of cancer progression. Cell 162 1229-1241. (https://doi.org/10.1016/j. cell.2015.08.016)

Chantranupong L, Scaria SM, Saxton RA, Gygi MP, Shen K, Wyant GA, Wang T, Harper JW, Gygi SP \& Sabatini DM 2016 The CASTOR proteins are arginine sensors for the mTORC1 pathway. Cell 165 153-164. (https://doi.org/10.1016/j.cell.2016.02.035) (c) 2019 The authors Published by Bioscientifica Ltd. Printed in Great Britain

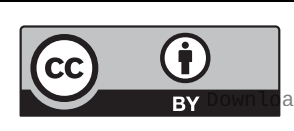

This work is licensed under a Creative Commons Attribution 4.0 Unported License.

ded from Bioscientifica.com at 04/26/2023 10:13:34AM 
Chauvin C, Koka V, Nouschi A, Mieulet V, Hoareau-Aveilla C, Dreazen A, Cagnard N, Carpentier W, Kiss T, Meyuhas O, et al. 2014 Ribosomal protein S6 kinase activity controls the ribosome biogenesis transcriptional program. Oncogene 33 474-483. (https://doi. org/10.1038/onc.2012.606)

Cheng JQ, Lindsley CW, Cheng GZ, Yang H \& Nicosia SV 2005 The Akt/ PKB pathway: molecular target for cancer drug discovery. Oncogene 24 7482-7492. (https://doi.org/10.1038/sj.onc.1209088)

Cho HJ, Park J, Lee HW, Lee YS \& Kim JB 2004 Regulation of adipocyte differentiation and insulin action with rapamycin. Biochemical and Biophysical Research Communications 321 942-948. (https://doi. org/10.1016/j.bbrc.2004.07.050)

Choi SY, Collins CC, Gout PW \& Wang Y 2013 Cancer-generated lactic acid: a regulatory, immunosuppressive metabolite? Journal of Pathology 230 350-355. (https://doi.org/10.1002/path.4218)

Cross DA, Alessi DR, Cohen P, Andjelkovich M \& Hemmings BA 1995 Inhibition of glycogen synthase kinase-3 by insulin mediated by protein kinase B. Nature 378 785-789. (https://doi org/10.1038/378785a0)

Csibi A, Fendt SM, Li C, Poulogiannis G, Choo AY, Chapski DJ, Jeong SM, Dempsey JM, Parkhitko A, Morrison T, et al. 2013 The mTORC1 pathway stimulates glutamine metabolism and cell proliferation by repressing SIRT4. Cell 153 840-854. (https://doi. org/10.1016/j.cell.2013.04.023)

Csibi A, Lee G, Yoon SO, Tong H, Ilter D, Elia I, Fendt SM, Roberts TM \& Blenis J 2014 The mTORC1/S6K1 pathway regulates glutamine metabolism through the eIF4B-dependent control of c-Myc translation. Current Biology 24 2274-2280. (https://doi.org/10.1016/j. cub.2014.08.007)

Cunningham JT, Rodgers JT, Arlow DH, Vazquez F, Mootha VK \& Puigserver P 2007 mTOR controls mitochondrial oxidative function through a YY1-PGC-1alpha transcriptional complex. Nature $\mathbf{4 5 0}$ 736-740. (https://doi.org/10.1038/nature06322)

Cunningham JT, Moreno MV, Lodi A, Ronen SM \& Ruggero D 2014 Protein and nucleotide biosynthesis are coupled by a single ratelimiting enzyme, PRPS2, to drive cancer. Cell 157 1088-1103. (https://doi.org/10.1016/j.cell.2014.03.052)

Cybulski N, Polak P, Auwerx J, Ruegg MA \& Hall MN 2009 mTOR complex 2 in adipose tissue negatively controls whole-body growth. PNAS 106 9902-9907. (https://doi.org/10.1073/pnas.0811321106)

Dang CV, Hamaker M, Sun P, Le A \& Gao P 2011 Therapeutic targeting of cancer cell metabolism. Journal of Molecular Medicine 89 205-212. (https://doi.org/10.1007/s00109-011-0730-x)

De Benedetti A \& Graff JR 2004 eIF-4E expression and its role in malignancies and metastases. Oncogene 23 3189-3199. (https://doi org/10.1038/sj.onc.1207545)

DeBerardinis RJ, Mancuso A, Daikhin E, Nissim I, Yudkoff M, Wehrli S \& Thompson CB 2007 Beyond aerobic glycolysis: transformed cells can engage in glutamine metabolism that exceeds the requirement for protein and nucleotide synthesis. PNAS 104 19345-19350. (https:// doi.org/10.1073/pnas.0709747104)

DeBerardinis RJ, Lum JJ, Hatzivassiliou G \& Thompson CB 2008 The biology of cancer: metabolic reprogramming fuels cell growth and proliferation. Cell Metabolism 7 11-20. (https://doi.org/10.1016/j. cmet.2007.10.002)

Deblois G, Smith HW, Tam IS, Gravel SP, Caron M, Savage P, Labbe DP, Begin LR, Tremblay ML, Park M, et al. 2016 ERRalpha mediates metabolic adaptations driving lapatinib resistance in breast cancer. Nature Communications 7 12156. (https://doi.org/10.1038/ ncomms12156)

Delgado-Goni T, Miniotis MF, Wantuch S, Parkes HG, Marais R, Workman P, Leach MO \& Beloueche-Babari M 2016 The BRAF inhibitor vemurafenib activates mitochondrial metabolism and inhibits hyperpolarized pyruvate-lactate exchange in BRAF-mutant human melanoma cells. Molecular Cancer Therapeutics 15 2987-2999. (https://doi.org/10.1158/1535-7163.MCT-16-0068)
Dennis MD, Jefferson LS \& Kimball SR 2012 Role of p70S6K1-mediated phosphorylation of eIF4B and PDCD4 proteins in the regulation of protein synthesis. Journal of Biological Chemistry 287 42890-42899. (https://doi.org/10.1074/jbc.M112.404822)

Deprez J, Vertommen D, Alessi DR, Hue L \& Rider MH 1997 Phosphorylation and activation of heart 6-phosphofructo-2-kinase by protein kinase $B$ and other protein kinases of the insulin signaling cascades. Journal of Biological Chemistry 272 17269-17275. (https://doi.org/10.1074/jbc.272.28.17269)

Dever TE \& Green R 2012 The elongation, termination, and recycling phases of translation in eukaryotes. Cold Spring Harbor Perspectives in Biology 4 a013706. (https://doi.org/10.1101/cshperspect.a013706)

DeYoung MP, Horak P, Sofer A, Sgroi D \& Ellisen LW 2008 Hypoxia regulates TSC1/2-mTOR signaling and tumor suppression through REDD1-mediated 14-3-3 shuttling. Genes and Development 22 239-251. (https://doi.org/10.1101/gad.1617608)

Dibble CC, Elis W, Menon S, Qin W, Klekota J, Asara JM, Finan PM, Kwiatkowski DJ, Murphy LO \& Manning BD 2012 TBC1D7 is a third subunit of the TSC1-TSC2 complex upstream of mTORC1. Molecular Cell 47 535-546. (https://doi.org/10.1016/j.molcel.2012.06.009)

Dickens F \& Williamson DH 1956 Pentose phosphate isomerase and epimerase from animal tissues. Biochemical Journal 64 567-578. (https://doi.org/10.1042/bj0640567)

Dodd KM, Yang J, Shen MH, Sampson JR \& Tee AR 2015 mTORC1 drives HIF-1alpha and VEGF-A signalling via multiple mechanisms involving 4E-BP1, S6K1 and STAT3. Oncogene 34 2239-2250. (https:// doi.org/10.1038/onc.2014.164)

Domchek SM, Auger KR, Chatterjee S, Burke TR Jr \& Shoelson SE 1992 Inhibition of SH2 domain/phosphoprotein association by a nonhydrolyzable phosphonopeptide. Biochemistry 31 9865-9870. (https://doi.org/10.1021/bi00156a002)

Dorrello NV, Peschiaroli A, Guardavaccaro D, Colburn NH, Sherman NE \& Pagano M 2006 S6K1- and betaTRCP-mediated degradation of PDCD4 promotes protein translation and cell growth. Science $\mathbf{3 1 4}$ 467-471. (https://doi.org/10.1126/science.1130276)

Dowling RJ, Topisirovic I, Alain T, Bidinosti M, Fonseca BD, Petroulakis E, Wang X, Larsson O, Selvaraj A, Liu Y, et al. 2010 mTORC1-mediated cell proliferation, but not cell growth, controlled by the 4E-BPs. Science 328 1172-1176. (https://doi.org/10.1126/ science.1187532)

Duvel K, Yecies JL, Menon S, Raman P, Lipovsky AI, Souza AL, Triantafellow E, Ma Q, Gorski R, Cleaver S, et al. 2010 Activation of a metabolic gene regulatory network downstream of mTOR complex 1. Molecular Cell 39 171-183. (https://doi.org/10.1016/j. molcel.2010.06.022)

Efeyan A, Zoncu R, Chang S, Gumper I, Snitkin H, Wolfson RL, Kirak O, Sabatini DD \& Sabatini DM 2013 Regulation of mTORC1 by the Rag GTPases is necessary for neonatal autophagy and survival. Nature 493 679-683. (https://doi.org/10.1038/nature11745)

Elfakess R, Sinvani H, Haimov O, Svitkin Y, Sonenberg N \& Dikstein R 2011 Unique translation initiation of mRNAs-containing TISU element. Nucleic Acids Research 39 7598-7609. (https://doi. org/10.1093/nar/gkr484)

Elstrom RL, Bauer DE, Buzzai M, Karnauskas R, Harris MH, Plas DR, Zhuang H, Cinalli RM, Alavi A, Rudin CM, et al. 2004 Akt stimulates aerobic glycolysis in cancer cells. Cancer Research 64 3892-3899. (https://doi.org/10.1158/0008-5472.CAN-03-2904)

Faes S, Demartines N \& Dormond O 2017 Resistance to mTORC1 inhibitors in cancer therapy: from kinase mutations to intratumoral heterogeneity of kinase activity. Oxidative Medicine and Cellular Longevity 2017 1726078. (https://doi.org/10.1155/2017/1726078)

Fasolo A \& Sessa C 2008 mTOR inhibitors in the treatment of cancer. Expert Opinion on Investigational Drugs 17 1717-1734. (https://doi.org /10.1517/13543784.17.11.1717)

Faubert B, Li KY, Cai L, Hensley CT, Kim J, Zacharias LG, Yang C, Do QN, Doucette S, Burguete D, et al. 2017 Lactate metabolism in

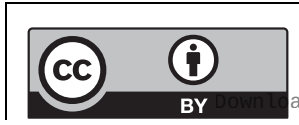

This work is licensed under a Creative Commons Attribution 4.0 Unported License. 
human lung tumors. Cell 171 358.e359-371.e359. (https://doi. org/10.1016/j.cell.2017.09.019)

Feng Y, Pinkerton AB, Hulea L, Zhang T, Davies MA, Grotegut S, Cheli Y, Yin H, Lau E, Kim H, et al. 2015 SBI-0640756 attenuates the growth of clinically unresponsive melanomas by disrupting the eIF4F translation initiation complex. Cancer Research 75 5211-5218. (https://doi.org/10.1158/0008-5472.CAN-15-0885)

Flynn A, Vries RG \& Proud CG 1997 Signalling pathways which regulate eIF4E. Biochemical Society Transactions 25 192S. (https://doi. org/10.1042/bst025192s)

Fonseca BD, Zakaria C, Jia JJ, Graber TE, Svitkin Y, Tahmasebi S, Healy D, Hoang HD, Jensen JM, Diao IT, et al. 2015 La-related protein 1 (LARP1) represses terminal oligopyrimidine (TOP) mRNA translation downstream of mTOR complex 1 (mTORC1). Journal of Biological Chemistry 290 15996-16020. (https://doi.org/10.1074/jbc. M114.621730)

Fraenkel M, Ketzinel-Gilad M, Ariav Y, Pappo O, Karaca M, Castel J, Berthault MF, Magnan C, Cerasi E, Kaiser N, et al. 2008 mTOR inhibition by rapamycin prevents beta-cell adaptation to hyperglycemia and exacerbates the metabolic state in type 2 diabetes. Diabetes 57 945-957. (https://doi.org/10.2337/db07-0922)

Fresno Vara JA, Casado E, de Castro J, Cejas P, Belda-Iniesta C \& Gonzalez-Baron M 2004 PI3K/Akt signalling pathway and cancer. Cancer Treatment Reviews 30 193-204. (https://doi.org/10.1016/j. ctrv.2003.07.007)

Furic L, Rong L, Larsson O, Koumakpayi IH, Yoshida K, Brueschke A, Petroulakis E, Robichaud N, Pollak M, Gaboury LA, et al. 2010 eIF4E phosphorylation promotes tumorigenesis and is associated with prostate cancer progression. PNAS 107 14134-14139. (https://doi. org/10.1073/pnas.1005320107)

Gandin V, Masvidal L, Hulea L, Gravel SP, Cargnello M, McLaughlan S, Cai Y, Balanathan P, Morita M, Rajakumar A, et al. 2016 nanoCAGE reveals $5^{\prime}$ UTR features that define specific modes of translation of functionally related MTOR-sensitive mRNAs. Genome Research $\mathbf{2 6}$ 636-648. (https://doi.org/10.1101/gr.197566.115)

Gentilella A, Kozma SC \& Thomas G 2015 A liaison between mTOR signaling, ribosome biogenesis and cancer. Biochimica et Biophysica Acta 1849 812-820. (https://doi.org/10.1016/j.bbagrm.2015.02.005)

Geyer CE, Forster J, Lindquist D, Chan S, Romieu CG, Pienkowski T, Jagiello-Gruszfeld A, Crown J, Chan A, Kaufman B, et al. 2006 Lapatinib plus capecitabine for HER2-positive advanced breast cancer. New England Journal of Medicine 355 2733-2743. (https://doi. org/10.1056/NEJMoa064320)

Gingras AC, Gygi SP, Raught B, Polakiewicz RD, Abraham RT, Hoekstra MF, Aebersold R \& Sonenberg N 1999 Regulation of 4E-BP1 phosphorylation: a novel two-step mechanism. Genes and Development 13 1422-1437. (https://doi.org/10.1101/gad.13.11.1422)

Gingras AC, Raught B, Gygi SP, Niedzwiecka A, Miron M, Burley SK, Polakiewicz RD, Wyslouch-Cieszynska A, Aebersold R \& Sonenberg N 2001 Hierarchical phosphorylation of the translation inhibitor 4E-BP1. Genes and Development 15 2852-2864. (https://doi. org/10.1101/gad.912401)

Glaser L \& Brown DH 1955 Purification and properties of d-glucose-6phosphate dehydrogenase. Journal of Biological Chemistry 216 67-79.

Gordan JD, Thompson CB \& Simon MC 2007 HIF and c-Myc: sibling rivals for control of cancer cell metabolism and proliferation. Cancer Cell 12 108-113. (https://doi.org/10.1016/j.ccr.2007.07.006)

Gottschalk S, Anderson N, Hainz C, Eckhardt SG \& Serkova NJ 2004 Imatinib (STI571)-mediated changes in glucose metabolism in human leukemia BCR-ABL-positive cells. Clinical Cancer Research 10 6661-6668. (https://doi.org/10.1158/1078-0432.CCR-04-0039)

Guan BJ, van Hoef V, Jobava R, Elroy-Stein O, Valasek LS, Cargnello M, Gao XH, Krokowski D, Merrick WC, Kimball SR, et al. 2017 A unique ISR program determines cellular responses to chronic stress. Molecular Cell 68 885.e886-900.e886. (https://doi.org/10.1016/j. molcel.2017.11.007) Printed in Great Britain
Gwinn DM, Shackelford DB, Egan DF, Mihaylova MM, Mery A, Vasquez DS, Turk BE \& Shaw RJ 2008 AMPK phosphorylation of raptor mediates a metabolic checkpoint. Molecular Cell 30 214-226. (https://doi.org/10.1016/j.molcel.2008.03.003)

Hagiwara A, Cornu M, Cybulski N, Polak P, Betz C, Trapani F, Terracciano L, Heim MH, Ruegg MA \& Hall MN 2012 Hepatic mTORC2 activates glycolysis and lipogenesis through Akt, glucokinase, and SREBP1c. Cell Metabolism 15 725-738. (https://doi. org/10.1016/j.cmet.2012.03.015)

Hagner PR, Schneider A \& Gartenhaus RB 2010 Targeting the translational machinery as a novel treatment strategy for hematologic malignancies. Blood 115 2127-2135. (https://doi. org/10.1182/blood-2009-09-220020)

Han J, Li E, Chen L, Zhang Y, Wei F, Liu J, Deng H \& Wang Y 2015 The CREB coactivator CRTC2 controls hepatic lipid metabolism by regulating SREBP1. Nature 524 243-246. (https://doi.org/10.1038/ nature14557)

Hanahan D \& Weinberg RA 2011 Hallmarks of cancer: the next generation. Cell 144 646-674. (https://doi.org/10.1016/j. cell.2011.02.013)

Harding MW, Galat A, Uehling DE \& Schreiber SL 1989 A receptor for the immunosuppressant FK506 is a cis-trans peptidyl-prolyl isomerase. Nature 341 758-760. (https://doi. org $/ 10.1038 / 341758 \mathrm{a} 0$ )

Hay N \& Sonenberg N 2004 Upstream and downstream of mTOR. Genes and Development 18 1926-1945. (https://doi.org/10.1101/ gad.1212704)

Hernandez-Davies JE, Tran TQ, Reid MA, Rosales KR, Lowman XH, Pan M, Moriceau G, Yang Y, Wu J, Lo RS, et al. 2015 Vemurafenib resistance reprograms melanoma cells towards glutamine dependence. Journal of Translational Medicine 13 210. (https://doi. org/10.1186/s12967-015-0581-2)

Hershey JW, Sonenberg N \& Mathews MB 2012 Principles of translational control: an overview. Cold Spring Harbor Perspectives in Biology 4 a011528. (https://doi.org/10.1101/cshperspect.a011528)

Hinnebusch AG 2014 The scanning mechanism of eukaryotic translation initiation. Annual Review of Biochemistry 83 779-812. (https://doi.org/10.1146/annurev-biochem-060713-035802)

Hirao T, Yamaguchi M, Kikuya M, Chibana H, Ito K \& Aoki S 2018 Altered intracellular signaling by imatinib increases the anti-cancer effects of tyrosine kinase inhibitors in chronic myelogenous leukemia cells. Cancer Science 109 121-131. (https://doi.org/10.1111/ cas.13442)

Ho PC, Bihuniak JD, Macintyre AN, Staron M, Liu X, Amezquita R, Tsui YC, Cui G, Micevic G, Perales JC, et al. 2015 Phosphoenolpyruvate is a metabolic checkpoint of anti-tumor T cell responses. Cell 162 1217-1228. (https://doi.org/10.1016/j. cell.2015.08.012)

Holz MK, Ballif BA, Gygi SP \& Blenis J 2005 mTOR and S6K1 mediate assembly of the translation preinitiation complex through dynamic protein interchange and ordered phosphorylation events. Cell 123 569-580. (https://doi.org/10.1016/j.cell.2005.10.024)

Hong S, Freeberg MA, Han T, Kamath A, Yao Y, Fukuda T, Suzuki T, Kim JK \& Inoki K 2017 LARP1 functions as a molecular switch for mTORC1-mediated translation of an essential class of mRNAs. Elife $\mathbf{6}$ e25237. (https://doi.org/10.7554/eLife.25237)

Horecker BL, Smyrniotis PZ \& Seegmiller JE 1951 The enzymatic conversion of 6-phosphogluconate to ribulose-5-phosphate and ribose-5-phosphate. Journal of Biological Chemistry 193 383-396.

Horton JD, Goldstein JL \& Brown MS 2002 SREBPs: transcriptional mediators of lipid homeostasis. Cold Spring Harbor Symposia on Quantitative Biology 67 491-498. (https://doi.org/10.1101/ sqb.2002.67.491)

Hove-Jensen B 1989 Phosphoribosylpyrophosphate (PRPP)-less mutants of Escherichia coli. Molecular Microbiology 3 1487-1492. (https://doi. org/10.1111/j.1365-2958.1989.tb00134.x)

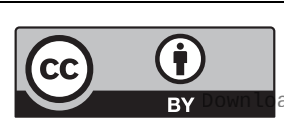

This work is licensed under a Creative Commons Attribution 4.0 Unported License. 
Hsieh AC, Liu Y, Edlind MP, Ingolia NT, Janes MR, Sher A, Shi EY, Stumpf CR, Christensen C, Bonham MJ, et al. 2012 The translational landscape of mTOR signalling steers cancer initiation and metastasis. Nature 485 55-61. (https://doi.org/10.1038/nature10912)

Hsu PP \& Sabatini DM 2008 Cancer cell metabolism: Warburg and beyond. Cell 134 703-707. (https://doi.org/10.1016/j. cell.2008.08.021)

Ilic N, Utermark T, Widlund HR \& Roberts TM 2011 PI3K-targeted therapy can be evaded by gene amplification along the MYCeukaryotic translation initiation factor $4 \mathrm{E}$ (eIF4E) axis. PNAS $\mathbf{1 0 8}$ E699-708. (https://doi.org/10.1073/pnas.1108237108)

Inoki K, Zhu T \& Guan KL 2003 TSC2 mediates cellular energy response to control cell growth and survival. Cell 115 577-590. (https://doi. org/10.1016/S0092-8674(03)00929-2)

Inoki K, Ouyang H, Zhu T, Lindvall C, Wang Y, Zhang X, Yang Q, Bennett C, Harada Y, Stankunas K, et al. 2006 TSC2 integrates Wnt and energy signals via a coordinated phosphorylation by AMPK and GSK3 to regulate cell growth. Cell 126 955-968. (https://doi. org/10.1016/j.cell.2006.06.055)

Jan E, Mohr I \& Walsh D 2016 A Cap-to-tail guide to mRNA translation strategies in virus-infected cells. Annual Review of Virology 3 283-307. (https://doi.org/10.1146/annurev-virology-100114-055014)

Javeshghani S, Zakikhani M, Austin S, Bazile M, Blouin MJ, Topisirovic I, St-Pierre J \& Pollak MN 2012 Carbon source and myc expression influence the antiproliferative actions of metformin. Cancer Research 72 6257-6267. (https://doi.org/10.1158/0008-5472.CAN-12-2907)

Jefferies HB, Reinhard C, Kozma SC \& Thomas G 1994 Rapamycin selectively represses translation of the 'polypyrimidine tract' mRNA family. PNAS 91 4441-4445. (https://doi.org/10.1073/pnas.91.10.4441)

Jefferies HB, Fumagalli S, Dennis PB, Reinhard C, Pearson RB \& Thomas G 1997 Rapamycin suppresses 5'TOP mRNA translation through inhibition of p70s6k. EMBO Journal 16 3693-3704. (https:// doi.org/10.1093/emboj/16.12.3693)

Jessani N, Humphrey M, McDonald WH, Niessen S, Masuda K, Gangadharan B, Yates JR 3rd, Mueller BM \& Cravatt BF 2004 Carcinoma and stromal enzyme activity profiles associated with breast tumor growth in vivo. PNAS 101 13756-13761. (https://doi org/10.1073/pnas.0404727101)

Johnson LF, Levis R, Abelson HT, Green H \& Penman S 1976 Changes in RNA in relation to growth of the fibroblast. IV. Alterations in theproduction and processing of mRNA and rRNA in resting and growing cells. Journal of Cell Biology 71 933-938. (https://doi. org/10.1083/jcb.71.3.933)

Jung J, Genau HM \& Behrends C 2015 Amino acid-dependent mTORC1 regulation by the lysosomal membrane protein SLC38A9. Molecular and Cellular Biology 35 2479-2494. (https://doi.org/10.1128/ MCB.00125-15)

Kahn BB, Alquier T, Carling D \& Hardie DG 2005 AMP-activated protein kinase: ancient energy gauge provides clues to modern understanding of metabolism. Cell Metabolism 1 15-25. (https://doi. org/10.1016/j.cmet.2004.12.003)

Kauffmann-Zeh A, Rodriguez-Viciana P, Ulrich E, Gilbert C, Coffer P, Downward J \& Evan G 1997 Suppression of c-Myc-induced apoptosis by Ras signalling through PI(3)K and PKB. Nature 385 544-548. (https://doi.org/10.1038/385544a0)

Keith B, Johnson RS \& Simon MC 2011 HIF1alpha and HIF2alpha: sibling rivalry in hypoxic tumour growth and progression. Nature Reviews Cancer 12 9-22. (https://doi.org/10.1038/nrc3183)

Kevil CG, De Benedetti A, Payne DK, Coe LL, Laroux FS \& Alexander JS 1996 Translational regulation of vascular permeability factor by eukaryotic initiation factor 4E: implications for tumor angiogenesis. International Journal of Cancer 65 785-790. (https://doi.org/10.1002/ (SICI)1097-0215(19960315)65:6<785::AID-IJC14>3.0.CO;2-3)

Kiel MC, Kaji H \& Kaji A 2007 Ribosome recycling: An essential process of protein synthesis. Biochemistry and Molecular Biology Education 35 40-44. (https://doi.org/10.1002/bmb.6) Printed in Great Britain
Kim JE \& Chen J 2004 regulation of peroxisome proliferator-activated receptor-gamma activity by mammalian target of rapamycin and amino acids in adipogenesis. Diabetes 53 2748-2756. (https://doi. org/10.2337/diabetes.53.11.2748)

Kim JW, Gao P, Liu YC, Semenza GL \& Dang CV 2007 Hypoxia-inducible factor 1 and dysregulated c-Myc cooperatively induce vascular endothelial growth factor and metabolic switches hexokinase 2 and pyruvate dehydrogenase kinase 1. Molecular and Cellular Biology 27 7381-7393. (https://doi.org/10.1128/MCB.00440-07)

Kim E, Goraksha-Hicks P, Li L, Neufeld TP \& Guan KL 2008 Regulation of TORC1 by Rag GTPases in nutrient response. Nature Cell Biology 10 935-945. (https://doi.org/10.1038/ncb1753)

Kim J, Kundu M, Viollet B \& Guan KL 2011 AMPK and mTOR regulate autophagy through direct phosphorylation of Ulk1. Nature Cell Biology 13 132-141. (https://doi.org/10.1038/ncb2152)

Knauf U, Tschopp C \& Gram H 2001 Negative regulation of protein translation by mitogen-activated protein kinase-interacting kinases 1 and 2. Molecular and Cellular Biology 21 5500-5511. (https://doi. org/10.1128/MCВ.21.16.5500-5511.2001)

Koh YK, Lee MY, Kim JW, Kim M, Moon JS, Lee YJ, Ahn YH \& Kim KS 2008 Lipin1 is a key factor for the maturation and maintenance of adipocytes in the regulatory network with CCAAT/enhancer-binding protein alpha and peroxisome proliferator-activated receptor gamma 2. Journal of Biological Chemistry 283 34896-34906. (https://doi. org/10.1074/jbc.M804007200)

Kohn AD, Summers SA, Birnbaum MJ \& Roth RA 1996 Expression of a constitutively active Akt Ser/Thr kinase in 3T3-L1 adipocytes stimulates glucose uptake and glucose transporter 4 translocation. Journal of Biological Chemistry 271 31372-31378. (https://doi. org/10.1074/jbc.271.49.31372)

Koromilas AE, Lazaris-Karatzas A \& Sonenberg N 1992 mRNAs containing extensive secondary structure in their $5^{\prime}$ non-coding region translate efficiently in cells overexpressing initiation factor eIF-4E. EMBO Journal 11 4153-4158.

Krall AS, Xu S, Graeber TG, Braas D \& Christofk HR 2016 Asparagine promotes cancer cell proliferation through use as an amino acid exchange factor. Nature Communications 7 11457. (https://doi. org/10.1038/ncomms11457)

Lamming DW, Ye L, Katajisto P, Goncalves MD, Saitoh M, Stevens DM, Davis JG, Salmon AB, Richardson A, Ahima RS, et al. 2012 Rapamycin-induced insulin resistance is mediated by mTORC2 loss and uncoupled from longevity. Science 335 1638-1643. (https://doi. org/10.1126/science.1215135)

Laplante M \& Sabatini DM 2009a An emerging role of mTOR in lipid biosynthesis. Current Biology 19 R1046-R1052. (https://doi. org/10.1016/j.cub.2009.09.058)

Laplante M \& Sabatini DM 2009b mTOR signaling at a glance. Journal of Cell Science 122 3589-3594. (https://doi.org/10.1242/jcs.051011)

Laplante M \& Sabatini DM 2012 mTOR Signaling in Growth Control and Disease. Cell 149 274-293. (https://doi.org/10.1016/j. cell.2012.03.017)

Larsson O, Perlman DM, Fan D, Reilly CS, Peterson M, Dahlgren C, Liang Z, Li S, Polunovsky VA, Wahlestedt C, et al. 2006 Apoptosis resistance downstream of eIF4E: posttranscriptional activation of an anti-apoptotic transcript carrying a consensus hairpin structure. Nucleic Acids Research 34 4375-4386. (https://doi.org/10.1093/nar/ gkl558)

Larsson O, Li S, Issaenko OA, Avdulov S, Peterson M, Smith K, Bitterman PB \& Polunovsky VA 2007 Eukaryotic translation initiation factor $4 \mathrm{E}$ induced progression of primary human mammary epithelial cells along the cancer pathway is associated with targeted translational deregulation of oncogenic drivers and inhibitors. Cancer Research 67 6814-6824. (https://doi. org/10.1158/0008-5472.CAN-07-0752)

Larsson O, Morita M, Topisirovic I, Alain T, Blouin MJ, Pollak M \& Sonenberg N 2012 Distinct perturbation of the translatome by the

This work is licensed under a Creative Commons Attribution 4.0 Unported License. 
antidiabetic drug metformin. PNAS 109 8977-8982. (https://doi. org/10.1073/pnas.1201689109)

Le Bacquer O, Petroulakis E, Paglialunga S, Poulin F, Richard D, Cianflone K \& Sonenberg N 2007 Elevated sensitivity to diet-induced obesity and insulin resistance in mice lacking 4E-BP1 and 4E-BP2. Journal of Clinical Investigation 117 387-396. (https://doi. org/10.1172/JCI29528)

Lemmon MA \& Schlessinger J 2010 Cell signaling by receptor tyrosine kinases. Cell 141 1117-1134. (https://doi.org/10.1016/j. cell.2010.06.011)

Li J, Kim SG \& Blenis J 2014a Rapamycin: one drug, many effects. Cell Metabolism 19 373-379. (https://doi.org/10.1016/j.cmet.2014.01.001)

Li JJ, Bickel PJ \& Biggin MD 2014b System wide analyses have underestimated protein abundances and the importance of transcription in mammals. PeerJ 2 e270. (https://doi.org/10.7717/ peerj.270)

Li S, Oh YT, Yue P, Khuri FR \& Sun SY 2016 Inhibition of mTOR complex 2 induces GSK3/FBXW7-dependent degradation of sterol regulatory element-binding protein 1 (SREBP1) and suppresses lipogenesis in cancer cells. Oncogene 35 642-650. (https://doi. org/10.1038/onc.2015.123)

Liu P, Cheng H, Roberts TM \& Zhao JJ 2009 Targeting the phosphoinositide 3-kinase pathway in cancer. Nature Reviews Drug Discovery 8 627-644. (https://doi.org/10.1038/nrd2926)

Locasale JW \& Cantley LC 2011 Metabolic flux and the regulation of mammalian cell growth. Cell Metabolism 14 443-451. (https://doi. org/10.1016/j.cmet.2011.07.014)

Long X, Lin Y, Ortiz-Vega S, Yonezawa K \& Avruch J 2005 Rheb binds and regulates the mTOR kinase. Current Biology 15 702-713. (https:// doi.org/10.1016/j.cub.2005.02.053)

Lunt SY \& Vander Heiden MG 2011 Aerobic glycolysis: meeting the metabolic requirements of cell proliferation. Annual Review of Cell and Developmental Biology 27 441-464. (https://doi.org/10.1146/ annurev-cellbio-092910-154237)

Malanga D, Scrima M, De Marco C, Fabiani F, De Rosa N, De Gisi S, Malara N, Savino R, Rocco G, Chiappetta G, et al. 2008 Activating E17K mutation in the gene encoding the protein kinase AKT1 in a subset of squamous cell carcinoma of the lung. Cell Cycle 7 665-669. (https://doi.org/10.4161/cc.7.5.5485)

Mamane Y, Petroulakis E, Rong L, Yoshida K, Ler LW \& Sonenberg N 2004 eIF4E - from translation to transformation. Oncogene 23 3172-3179. (https://doi.org/10.1038/sj.onc.1207549)

Martelli AM, Evangelisti C, Chappell W, Abrams SL, Basecke J, Stivala F, Donia M, Fagone P, Nicoletti F, Libra M, et al. 2011 Targeting the translational apparatus to improve leukemia therapy: roles of the PI3K/PTEN/Akt/mTOR pathway. Leukemia 25 1064-1079. (https:// doi.org/10.1038/leu.2011.46)

Martelli AM, Chiarini F, Evangelisti C, Cappellini A, Buontempo F, Bressanin D, Fini M \& McCubrey JA 2012 Two hits are better than one: targeting both phosphatidylinositol 3-kinase and mammalian target of rapamycin as a therapeutic strategy for acute leukemia treatment. Oncotarget 3 371-394. (https://doi.org/10.18632/ oncotarget.477)

Masui K, Tanaka K, Akhavan D, Babic I, Gini B, Matsutani T, Iwanami A, Liu F, Villa GR, Gu Y, et al. 2013 mTOR complex 2 controls glycolytic metabolism in glioblastoma through FoxO acetylation and upregulation of c-Myc. Cell Metabolism 18 726-739. (https://doi. org/10.1016/j.cmet.2013.09.013)

Masui K, Cavenee WK \& Mischel PS 2014 mTORC2 in the center of cancer metabolic reprogramming. Trends in Endocrinology and Metabolism 25 364-373. (https://doi.org/10.1016/j.tem.2014.04.002)

Maxwell PH, Wiesener MS, Chang GW, Clifford SC, Vaux EC, Cockman ME, Wykoff CC, Pugh CW, Maher ER \& Ratcliffe PJ 1999 The tumour suppressor protein VHL targets hypoxia-inducible factors for oxygen-dependent proteolysis. Nature 399 271-275. (https://doi.org/10.1038/20459) Printed in Great Britain
Memmott RM \& Dennis PA 2009 Akt-dependent and -independent mechanisms of mTOR regulation in cancer. Cellular Signalling 21 656-664. (https://doi.org/10.1016/j.cellsig.2009.01.004)

Menendez JA \& Lupu R 2007 Fatty acid synthase and the lipogenic phenotype in cancer pathogenesis. Nature Reviews Cancer 7 763-777. (https://doi.org/10.1038/nrc2222)

Meyuhas O \& Dreazen A 2009 Ribosomal protein S6 kinase from TOP mRNAs to cell size. Progress in Molecular Biology and Translational Science 90 109-153. (https://doi.org/10.1016/S1877-1173(09)90003-5)

Miloslavski R, Cohen E, Avraham A, Iluz Y, Hayouka Z, Kasir J, Mudhasani R, Jones SN, Cybulski N, Ruegg MA, et al. 2014 Oxygen sufficiency controls TOP mRNA translation via the TSC-Rheb-mTOR pathway in a 4E-BP-independent manner. Journal of Molecular Cell Biology 6 255-266. (https://doi.org/10.1093/jmcb/mju008)

Mohr I \& Sonenberg N 2012 Host translation at the nexus of infection and immunity. Cell Host and Microbe 12 470-483. (https://doi. org/10.1016/j.chom.2012.09.006)

Morita M, Gravel SP, Chenard V, Sikstrom K, Zheng L, Alain T, Gandin V, Avizonis D, Arguello M, Zakaria C, et al. 2013 mTORC1 controls mitochondrial activity and biogenesis through 4E-BPdependent translational regulation. Cell Metabolism 18 698-711. (https://doi.org/10.1016/j.cmet.2013.10.001)

Morita M, Prudent J, Basu K, Goyon V, Katsumura S, Hulea L, Pearl D, Siddiqui N, Strack S, McGuirk S, et al. 2017 mTOR controls mitochondrial dynamics and cell survival via MTFP1. Molecular Cell 67 922.e925-935.e925. (https://doi.org/10.1016/j. molcel.2017.08.013)

Myers AP \& Cantley LC 2010 Targeting a common collaborator in cancer development. Science Translational Medicine 2 48ps45. (https:// doi.og/10.1126/scitranslmed.3001251)

Nikiforov MA, Chandriani S, O'Connell B, Petrenko O, Kotenko I, Beavis A, Sedivy JM \& Cole MD 2002 A functional screen for Mycresponsive genes reveals serine hydroxymethyltransferase, a major source of the one-carbon unit for cell metabolism. Molecular and Cellular Biology 22 5793-5800. (https://doi.org/10.1128/ MCB.22.16.5793-5800.2002)

Oh WJ \& Jacinto E 2011 mTOR complex 2 signaling and functions. Cell Cycle 10 2305-2316. (https://doi.org/10.4161/cc.10.14.16586)

Osthus RC, Shim H, Kim S, Li Q, Reddy R, Mukherjee M, Xu Y, Wonsey D, Lee LA \& Dang CV 2000 Deregulation of glucose transporter 1 and glycolytic gene expression by c-Myc. Journal of Biological Chemistry 275 21797-21800. (https://doi.org/10.1074/jbc. C000023200)

Oudejans RCHM, Schoonen WGEJ \& Voogt PA 1983 Production of $\mathrm{NADPH}$ and acetyl CoA for lipid biosynthesis in the pyloric caeca of the sea star, Asterias rubens. Comparative Biochemistry and Physiology Part B: Comparative Biochemistry 74 351-355. (https://doi. org/10.1016/0305-0491(83)90024-X)

Paech F, Bouitbir J \& Krahenbuhl S 2017 Hepatocellular toxicity associated with tyrosine kinase inhibitors: mitochondrial damage and inhibition of glycolysis. Frontiers in Pharmacology 8 367. (https:// doi.org/10.3389/fphar.2017.00367)

Park S, Chang CY, Safi R, Liu X, Baldi R, Jasper JS, Anderson GR, Liu T, Rathmell JC, Dewhirst MW, et al. 2016 ERRalpha-regulated lactate metabolism contributes to resistance to targeted therapies in breast cancer. Cell Reports 15 323-335. (https://doi.org/10.1016/j. celrep.2016.03.026)

Patel MR, Jay-Dixon J, Sadiq AA, Jacobson BA \& Kratzke RA 2013 Resistance to EGFR-TKI can be mediated through multiple signaling pathways converging upon cap-dependent translation in EGFR-wild type NSCLC. Journal of Thoracic Oncology 8 1142-1147. (https://doi. org/10.1097/JTO.0b013e31829ce963)

Pause A, Belsham GJ, Gingras AC, Donze O, Lin TA, Lawrence JC Jr \& Sonenberg N 1994 Insulin-dependent stimulation of protein synthesis by phosphorylation of a regulator of $5^{\prime}$-cap function. Nature 371 762-767. (https://doi.org/10.1038/371762a0)

This work is licensed under a Creative Commons Attribution 4.0 Unported License. 
Pende M, Um SH, Mieulet V, Sticker M, Goss VL, Mestan J, Mueller M, Fumagalli S, Kozma SC \& Thomas G 2004 S6K1(-/-)/S6K2(-/-) mice exhibit perinatal lethality and rapamycin-sensitive 5 '-terminal oligopyrimidine mRNA translation and reveal a mitogen-activated protein kinase-dependent S6 kinase pathway. Molecular and Cellular Biology 24 3112-3124. (https://doi.org/10.1128/MCB.24.8.31123124.2004)

Peng T, Golub TR \& Sabatini DM 2002 The immunosuppressant rapamycin mimics a starvation-like signal distinct from amino acid and glucose deprivation. Molecular and Cellular Biology 22 5575-5584. (https://doi.org/10.1128/MCB.22.15.5575-5584.2002)

Peterson TR, Sengupta SS, Harris TE, Carmack AE, Kang SA, Balderas E, Guertin DA, Madden KL, Carpenter AE, Finck BN, et al. 2011 mTOR complex 1 regulates lipin 1 localization to control the SREBP pathway. Cell 146 408-420. (https://doi.org/10.1016/j. cell.2011.06.034)

Pfeiffer T, Schuster S \& Bonhoeffer S 2001 Cooperation and competition in the evolution of ATP-producing pathways. Science 292 504-507. (https://doi.org/10.1126/science.1058079)

Philippe L, Vasseur JJ, Debart F \& Thoreen CC 2018 La-related protein 1 (LARP1) repression of TOP mRNA translation is mediated through its cap-binding domain and controlled by an adjacent regulatory region. Nucleic Acids Research 46 1457-1469. (https://doi. org/10.1093/nar/gkx1237)

Pianese G 1896 Beitrag zur histologie und aetiologie der carcinoma: histologische und experimentelle untersuchungen. Beiträge zur pathologischen Anatomie und zur allgemeinen Pathologie. 142 1-193.

Pollak M 2010 Metformin and other biguanides in oncology: advancing the research agenda. Cancer Prevention Research 3 1060-1065. (https://doi.org/10.1158/1940-6207.CAPR-10-0175)

Populo H, Lopes JM \& Soares P 2012 The mTOR signalling pathway in human cancer. International Journal of Molecular Sciences $\mathbf{1 3}$ 1886-1918. (https://doi.org/10.3390/ijms13021886)

Porstmann T, Santos CR, Griffiths B, Cully M, Wu M, Leevers S, Griffiths JR, Chung YL \& Schulze A 2008 SREBP activity is regulated by mTORC1 and contributes to Akt-dependent cell growth. Cell Metabolism 8 224-236. (https://doi.org/10.1016/j. cmet.2008.07.007)

Porta C, Paglino C \& Mosca A 2014 Targeting PI3K/Akt/mTOR signaling in cancer. Frontiers in Oncology 4 64. (https://doi.org/10.3389/ fonc.2014.00064)

Poulikakos PI, Persaud Y, Janakiraman M, Kong X, Ng C, Moriceau G, Shi H, Atefi M, Titz B, Gabay MT, et al. 2011 RAF inhibitor resistance is mediated by dimerization of aberrantly spliced BRAF(V600E). Nature 480 387-390. (https://doi.org/10.1038/nature10662)

Proud CG 2013 mTORC1 regulates the efficiency and cellular capacity for protein synthesis. Biochemical Society Transactions 41 923-926. (https://doi.org/10.1042/BST20130036)

Pyronnet S, Imataka H, Gingras AC, Fukunaga R, Hunter T \& Sonenberg N 1999 Human eukaryotic translation initiation factor 4G (eIF4G) recruits mnk1 to phosphorylate eIF4E. EMBO Journal 18 270-279. (https://doi.org/10.1093/emboj/18.1.270)

Ramanathan A \& Schreiber SL 2009 Direct control of mitochondrial function by mTOR. PNAS 106 22229-22232. (https://doi. org/10.1073/pnas.0912074106)

Raught B, Peiretti F, Gingras AC, Livingstone M, Shahbazian D, Mayeur GL, Polakiewicz RD, Sonenberg N \& Hershey JW 2004 Phosphorylation of eucaryotic translation initiation factor 4B Ser422 is modulated by S6 kinases. EMBO Journal 23 1761-1769. (https:// doi.org/10.1038/sj.emboj.7600193)

Reitzer LJ, Wice BM \& Kennell D 1979 Evidence that glutamine, not sugar, is the major energy source for cultured HeLa cells. Journal of Biological Chemistry 254 2669-2676.

Robichaud N, del Rincon SV, Huor B, Alain T, Petruccelli LA, Hearnden J, Goncalves C, Grotegut S, Spruck CH, Furic L, et al. 2015 Phosphorylation of eIF4E promotes EMT and metastasis via translational control of SNAIL and MMP-3. Oncogene 34 2032-2042. (https://doi.org/10.1038/onc.2014.146)

Robitaille AM, Christen S, Shimobayashi M, Cornu M, Fava LL, Moes S, Prescianotto-Baschong C, Sauer U, Jenoe P \& Hall MN 2013 Quantitative phosphoproteomics reveal mTORC1 activates de novo pyrimidine synthesis. Science 339 1320-1323. (https://doi. org/10.1126/science.1228771)

Rodrik-Outmezguine VS, Okaniwa M, Yao Z, Novotny CJ, McWhirter C, Banaji A, Won H, Wong W, Berger M, de Stanchina E, et al. 2016 Overcoming mTOR resistance mutations with a new-generation mTOR inhibitor. Nature 534 272-276. (https://doi.org/10.1038/ nature17963)

Rogers GW Jr, Richter NJ \& Merrick WC 1999 Biochemical and kinetic characterization of the RNA helicase activity of eukaryotic initiation factor 4A. Journal of Biological Chemistry 274 12236-12244. (https:// doi.org/10.1074/jbc.274.18.12236)

Rolfe DF \& Brown GC 1997 Cellular energy utilization and molecular origin of standard metabolic rate in mammals. Physiological Reviews 77 731-758. (https://doi.org/10.1152/physrev.1997.77.3.731)

Roux PP \& Topisirovic I 2012 Regulation of mRNA translation by signaling pathways. Cold Spring Harbor Perspectives in Biology 4 a012252. (https://doi.org/10.1101/cshperspect.a012252)

Roux PP \& Topisirovic I 2018 Signaling pathways involved in the regulation of mRNA translation. Molecular and Cellular Biology $\mathbf{3 8}$ e00070-18. (https://doi.org/10.1128/MCB.00070-18)

Roux PP, Ballif BA, Anjum R, Gygi SP \& Blenis J 2004 Tumor-promoting phorbol esters and activated Ras inactivate the tuberous sclerosis tumor suppressor complex via p90 ribosomal S6 kinase. PNAS 101 13489-13494. (https://doi.org/10.1073/pnas.0405659101)

Ruggero D 2013 Translational control in cancer etiology. Cold Spring Harbor Perspectives in Biology 5 a012336. (https://doi.org/10.1101/ cshperspect.a012336)

Ruggero D \& Sonenberg N 2005 The Akt of translational control. Oncogene 24 7426-7434. (https://doi.org/10.1038/sj.onc.1209098)

Ruvinsky I, Sharon N, Lerer T, Cohen H, Stolovich-Rain M, Nir T, Dor Y, Zisman P \& Meyuhas O 2005 Ribosomal protein S6 phosphorylation is a determinant of cell size and glucose homeostasis. Genes and Development 19 2199-2211. (https://doi.org/10.1101/gad.351605)

Sancak Y, Thoreen CC, Peterson TR, Lindquist RA, Kang SA, Spooner E, Carr SA \& Sabatini DM 2007 PRAS40 is an insulin-regulated inhibitor of the mTORC1 protein kinase. Molecular Cell 25 903-915. (https://doi.org/10.1016/j.molcel.2007.03.003)

Sancak Y, Peterson TR, Shaul YD, Lindquist RA, Thoreen CC, Bar-Peled L \& Sabatini DM 2008 The Rag GTPases bind raptor and mediate amino acid signaling to mTORC1. Science 320 1496-1501. (https:// doi.org/10.1126/science.1157535)

Sancak Y, Bar-Peled L, Zoncu R, Markhard AL, Nada S \& Sabatini DM 2010 Ragulator-Rag complex targets mTORC1 to the lysosomal surface and is necessary for its activation by amino acids. Cell $\mathbf{1 4 1}$ 290-303. (https://doi.org/10.1016/j.cell.2010.02.024)

Sarbassov DD, Ali SM, Sengupta S, Sheen JH, Hsu PP, Bagley AF, Markhard AL \& Sabatini DM 2006 Prolonged rapamycin treatment inhibits mTORC2 assembly and Akt/PKB. Molecular Cell 22 159-168. (https://doi.org/10.1016/j.molcel.2006.03.029)

Saxton RA \& Sabatini DM 2017 mTOR signaling in growth, metabolism, and disease. Cell 169 361-371. (https://doi.org/10.1016/j. cell.2017.03.035)

Scheper GC, van Kollenburg B, Hu J, Luo Y, Goss DJ \& Proud CG 2002 Phosphorylation of eukaryotic initiation factor $4 \mathrm{E}$ markedly reduces its affinity for capped mRNA. Journal of Biological Chemistry 277 3303-3309. (https://doi.org/10.1074/jbc.M103607200)

Schieke SM, Phillips D, McCoy JP Jr, Aponte AM, Shen RF, Balaban RS \& Finkel T 2006 The mammalian target of rapamycin (mTOR) pathway regulates mitochondrial oxygen consumption and oxidative capacity. Journal of Biological Chemistry 281 27643-27652. (https://doi. org/10.1074/jbc.M603536200)

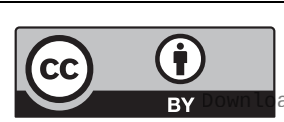

This work is licensed under a Creative Commons Attribution 4.0 Unported License. 
Schlessinger J 2002 Ligand-induced, receptor-mediated dimerization and activation of EGF receptor. Cell 110 669-672. (https://doi. org/10.1016/S0092-8674(02)00966-2)

Schwanhausser B, Busse D, Li N, Dittmar G, Schuchhardt J, Wolf J, Chen W \& Selbach M 2011 Global quantification of mammalian gene expression control. Nature 473 337-342. (https://doi. org/10.1038/nature10098)

Semenza GL 2000 HIF-1: mediator of physiological and pathophysiological responses to hypoxia. Journal of Applied Physiology 88 1474-1480. (https://doi.org/10.1152/jappl.2000.88.4.1474)

Semenza GL 2007 Hypoxia-inducible factor 1 (HIF-1) pathway. Science STKE 2007 cm8. (https://doi.org/10.1126/stke.4072007cm8)

Shaw RJ 2009 LKB1 and AMP-activated protein kinase control of mTOR signalling and growth. Acta Physiologica 196 65-80. (https://doi. org/10.1111/j.1748-1716.2009.01972.x)

Shaw RJ, Bardeesy N, Manning BD, Lopez L, Kosmatka M, DePinho RA \& Cantley LC 2004a The LKB1 tumor suppressor negatively regulates mTOR signaling. Cancer Cell 6 91-99. (https://doi.org/10.1016/i. ccr.2004.06.007)

Shaw RJ, Kosmatka M, Bardeesy N, Hurley RL, Witters LA, DePinho RA \& Cantley LC 2004b The tumor suppressor LKB1 kinase directly activates AMP-activated kinase and regulates apoptosis in response to energy stress. PNAS 101 3329-3335. (https://doi.org/10.1073/ pnas.0308061100)

Shestov AA, Liu X, Ser Z, Cluntun AA, Hung YP, Huang L, Kim D, Le A, Yellen G, Albeck JG, et al. 2014 Quantitative determinants of aerobic glycolysis identify flux through the enzyme GAPDH as a limiting step. Elife 3. (https://doi.org/10.7554/eLife.03342)

Shim H, Dolde C, Lewis BC, Wu CS, Dang G, Jungmann RA, DallaFavera R \& Dang CV 1997 c-Myc transactivation of LDH-A: implications for tumor metabolism and growth. PNAS 94 6658-6663. (https://doi.org/10.1073/pnas.94.13.6658)

Shimobayashi M \& Hall MN 2014 Making new contacts: the mTOR network in metabolism and signalling crosstalk. Nature Reviews Molecular Cell Biology 15 155-162. (https://doi.org/10.1038/nrm3757)

Shuvalov O, Petukhov A, Daks A, Fedorova O, Vasileva E \& Barlev NA 2017 One-carbon metabolism and nucleotide biosynthesis as attractive targets for anticancer therapy. Oncotarget 8 23955-23977.

Siekierka JJ, Hung SH, Poe M, Lin CS \& Sigal NH 1989 A cytosolic binding protein for the immunosuppressant FK506 has peptidylprolyl isomerase activity but is distinct from cyclophilin. Nature $\mathbf{3 4 1}$ 755-757. (https://doi.org/10.1038/341755a0)

Silvera D, Formenti SC \& Schneider RJ 2010 Translational control in cancer. Nature Reviews Cancer 10 254-266. (https://doi.org/10.1038/ nrc2824)

Slepenkov SV, Darzynkiewicz E \& Rhoads RE 2006 Stopped-flow kinetic analysis of eIF4E and phosphorylated eIF4E binding to cap analogs and capped oligoribonucleotides: evidence for a one-step binding mechanism. Journal of Biological Chemistry 281 14927-14938. (https://doi.org/10.1074/jbc.M601653200)

Slomovitz BM \& Coleman RL 2012 The PI3K/AKT/mTOR pathway as a therapeutic target in endometrial cancer. Clinical Cancer Research 18 5856-5864. (https://doi.org/10.1158/1078-0432.CCR-12-0662)

Smallbone K, Gavaghan DJ, Gatenby RA \& Maini PK 2005 The role of acidity in solid tumour growth and invasion. Journal of Theoretical Biology 235 476-484. (https://doi.org/10.1016/j.jtbi.2005.02.001)

Sonenberg N \& Hinnebusch AG 2009 Regulation of translation initiation in eukaryotes: mechanisms and biological targets. Cell 136 731-745. (https://doi.org/10.1016/j.cell.2009.01.042)

Soukas AA, Kane EA, Carr CE, Melo JA \& Ruvkun G 2009 Rictor/TORC2 regulates fat metabolism, feeding, growth, and life span in Caenorhabditis elegans. Genes and Development 23 496-511. (https:// doi.org/10.1101/gad.1775409)

Spriggs KA, Bushell M \& Willis AE 2010 Translational regulation of gene expression during conditions of cell stress. Molecular Cell $\mathbf{4 0}$ 228-237. (https://doi.org/10.1016/j.molcel.2010.09.028) Printed in Great Britain
Stambolic V, Suzuki A, de la Pompa JL, Brothers GM, Mirtsos C, Sasaki T, Ruland J, Penninger JM, Siderovski DP \& Mak TW 1998 Negative regulation of $\mathrm{PKB} /$ Akt-dependent cell survival by the tumor suppressor PTEN. Cell 95 29-39. (https://doi.org/10.1016/S00928674(00)81780-8)

Stark H, Rodnina MV, Wieden HJ, van Heel M \& Wintermeyer W 2000 Large-scale movement of elongation factor $\mathrm{G}$ and extensive conformational change of the ribosome during translocation. Cell 100 301-309. (https://doi.org/10.1016/S0092-8674(00)80666-2)

Starosta AL, Lassak J, Jung K \& Wilson DN 2014 The bacterial translation stress response. FEMS Microbiology Reviews 38 1172-1201. (https://doi.org/10.1111/1574-6976.12083)

Stine ZE, Walton ZE, Altman BJ, Hsieh AL \& Dang CV 2015 MYC, metabolism, and cancer. Cancer Discovery 5 1024-1039. (https://doi. org/10.1158/2159-8290.CD-15-0507)

Svitkin YV, Pause A, Haghighat A, Pyronnet S, Witherell G, Belsham GJ \& Sonenberg N 2001 The requirement for eukaryotic initiation factor $4 \mathrm{~A}$ (elF4A) in translation is in direct proportion to the degree of mRNA 5' secondary structure. RNA 7 382-394. (https://doi. org/10.1017/S135583820100108X)

Taylor DJ, Nilsson J, Merrill AR, Andersen GR, Nissen P \& Frank J 2007 Structures of modified eEF2 $80 \mathrm{~S}$ ribosome complexes reveal the role of GTP hydrolysis in translocation. EMBO Journal 26 2421-2431. (https://doi.org/10.1038/sj.emboj.7601677)

Tcherkezian J, Cargnello M, Romeo Y, Huttlin EL, Lavoie G, Gygi SP \& Roux PP 2014 Proteomic analysis of cap-dependent translation identifies LARP1 as a key regulator of 5'TOP mRNA translation. Genes and Development 28 357-371. (https://doi.org/10.1101/ gad.231407.113)

Thoreen CC, Chantranupong L, Keys HR, Wang T, Gray NS \& Sabatini DM 2012 A unifying model for mTORC1-mediated regulation of mRNA translation. Nature 485 109-113. (https://doi org/10.1038/nature11083)

Topisirovic I \& Sonenberg N 2011 mRNA translation and energy metabolism in cancer: the role of the MAPK and mTORC1 pathways. Cold Spring Harbor Symposia on Quantitative Biology 76 355-367. (https://doi.org/10.1101/sqb.2011.76.010785)

Topisirovic I, Ruiz-Gutierrez M \& Borden KL 2004 Phosphorylation of the eukaryotic translation initiation factor eIF4E contributes to its transformation and mRNA transport activities. Cancer Research 64 8639-8642. (https://doi.org/10.1158/0008-5472.CAN-04-2677)

Um SH, Frigerio F, Watanabe M, Picard F, Joaquin M, Sticker M, Fumagalli S, Allegrini PR, Kozma SC, Auwerx J, et al. 2004 Absence of $\mathrm{S} 6 \mathrm{~K} 1$ protects against age- and diet-induced obesity while enhancing insulin sensitivity. Nature 431 200-205. (https://doi. org/10.1038/nature02866)

van Riggelen J, Yetil A \& Felsher DW 2010 MYC as a regulator of ribosome biogenesis and protein synthesis. Nature Reviews Cancer 10 301-309. (https://doi.org/10.1038/nrc2819)

Vander Heiden MG, Cantley LC \& Thompson CB 2009 Understanding the Warburg effect: the metabolic requirements of cell proliferation. Science 324 1029-1033. (https://doi.org/10.1126/ science.1160809)

Wan X, Harkavy B, Shen N, Grohar P \& Helman LJ 2007 Rapamycin induces feedback activation of Akt signaling through an IGF-1Rdependent mechanism. Oncogene 26 1932-1940. (https;//doi. org/10.1038/sj.onc.1209990)

Wang X \& Proud CG 2006 The mTOR pathway in the control of protein synthesis. Physiology 21 362-369. (https://doi.org/10.1152/ physiol.00024.2006)

Wang X, Li W, Williams M, Terada N, Alessi DR \& Proud CG 2001 Regulation of elongation factor 2 kinase by p90(RSK1) and p70 S6 kinase. EMBO Journal 20 4370-4379. (https://doi.org/10.1093/ emboj/20.16.4370)

Wang W, Fridman A, Blackledge W, Connelly S, Wilson IA, Pilz RB \& Boss GR 2009 The phosphatidylinositol 3-kinase/akt cassette

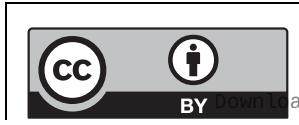

This work is licensed under a Creative Commons Attribution 4.0 Unported License. 
regulates purine nucleotide synthesis. Journal of Biological Chemistry 284 3521-3528. (https://doi.org/10.1074/jbc.M806707200)

Warburg O 1925 The metabolism of carcinoma cells. Journal of Cancer Research 9 148-163. (https://doi.org/10.1158/jcr.1925.148)

Warburg O 1956 On the origin of cancer cells. Science 123 309-314. (https://doi.org/10.1126/science.123.3191.309)

Ward PS \& Thompson CB 2012 Metabolic reprogramming: a cancer hallmark even warburg did not anticipate. Cancer Cell 21 297-308. (https://doi.org/10.1016/j.ccr.2012.02.014)

Waskiewicz AJ, Flynn A, Proud CG \& Cooper JA 1997 Mitogen-activated protein kinases activate the serine/threonine kinases Mnk1 and Mnk2. EMBO Journal 16 1909-1920. (https://doi.org/10.1093/emboj/16.8.1909)

Waskiewicz AJ, Johnson JC, Penn B, Mahalingam M, Kimball SR \& Cooper JA 1999 Phosphorylation of the cap-binding protein eukaryotic translation initiation factor $4 \mathrm{E}$ by protein kinase Mnk1 in vivo. Molecular and Cellular Biology 19 1871-1880. (https://doi. org/10.1128/MCB.19.3.1871)

Wendel HG, Silva RL, Malina A, Mills JR, Zhu H, Ueda T, WatanabeFukunaga R, Fukunaga R, Teruya-Feldstein J, Pelletier J, et al. 2007 Dissecting eIF4E action in tumorigenesis. Genes and Development 21 3232-3237. (https://doi.org/10.1101/gad.1604407)

Wenger RH 2000 Mammalian oxygen sensing, signalling and gene regulation. Journal of Experimental Biology 203 1253-1263.

Wheaton WW, Weinberg SE, Hamanaka RB, Soberanes S, Sullivan LB, Anso E, Glasauer A, Dufour E, Mutlu GM, Budigner GS, et al. 2014 Metformin inhibits mitochondrial complex I of cancer cells to reduce tumorigenesis. Elife 3 e02242. (https;//doi.org/10.7554/ eLife.02242)

Whiteman EL, Cho H \& Birnbaum MJ 2002 Role of Akt/protein kinase B in metabolism. Trends in Endocrinology and Metabolism 13 444-451. (https://doi.org/10.1016/S1043-2760(02)00662-8)

Winkler BS, DeSantis N \& Solomon F 1986 Multiple NADPH-producing pathways control glutathione (GSH) content in retina. Experimental Eye Research 43 829-847. (https://doi.org/10.1016/S00144835(86)80013-6)

Wise DR \& Thompson CB 2010 Glutamine addiction: a new therapeutic target in cancer. Trends in Biochemical Sciences 35 427-433. (https:// doi.org/10.1016/j.tibs.2010.05.003)

Wise DR, DeBerardinis RJ, Mancuso A, Sayed N, Zhang XY, Pfeiffer HK, Nissim I, Daikhin E, Yudkoff M, McMahon SB, et al. 2008 Myc regulates a transcriptional program that stimulates mitochondrial glutaminolysis and leads to glutamine addiction. PNAS $\mathbf{1 0 5}$ 18782-18787. (https://doi.org/10.1073/pnas.0810199105)

Wolfson RL, Chantranupong L, Wyant GA, Gu X, Orozco JM, Shen K, Condon KJ, Petri S, Kedir J, Scaria SM, et al. 2017 KICSTOR recruits GATOR1 to the lysosome and is necessary for nutrients to regulate mTORC1. Nature 543 438-442. (https://doi.org/10.1038/nature21423)

Yang H, Rudge DG, Koos JD, Vaidialingam B, Yang HJ \& Pavletich NP 2013 mTOR kinase structure, mechanism and regulation. Nature $\mathbf{4 9 7}$ 217-223. (https://doi.org/10.1038/nature12122)
Yao R \& Cooper GM 1995 Requirement for phosphatidylinositol-3 kinase in the prevention of apoptosis by nerve growth factor. Science 267 2003-2006. (https://doi.org/10.1126/science.7701324)

Yecies JL \& Manning BD 2011 Transcriptional control of cellular metabolism by mTOR signaling. Cancer Research 71 2815-2820. (https://doi.org/10.1158/0008-5472.CAN-10-4158)

Young K, Minchom A \& Larkin J 2012 BRIM-1, -2 and -3 trials: improved survival with vemurafenib in metastatic melanoma patients with a BRAFV600E mutation. Future Oncology 8 499-507. (https://doi.org/10.2217/fon.12.43)

Yuan P, Ito K, Perez-Lorenzo R, Del Guzzo C, Lee JH, Shen CH, Bosenberg MW, McMahon M, Cantley LC \& Zheng B 2013 Phenformin enhances the therapeutic benefit of BRAF(V600E) inhibition in melanoma. PNAS 110 18226-18231. (https://doi. org/10.1073/pnas.1317577110)

Zech R, Kiontke S, Mueller U, Oeckinghaus A \& Kummel D 2016 Structure of the tuberous sclerosis complex 2 (TSC2) N terminus provides insight into complex assembly and tuberous sclerosis pathogenesis. Journal of Biological Chemistry 291 20008-20020. (https://doi.org/10.1074/jbc.M116.732446)

Zhan Y, Dahabieh MS, Rajakumar A, Dobocan MC, M'Boutchou MN, Goncalves C, Lucy SL, Pettersson F, Topisirovic I, van Kempen L, et al. 2015 The role of eIF4E in response and acquired resistance to vemurafenib in melanoma. Journal of Investigative Dermatology 135 1368-1376. (https://doi.org/10.1038/jid.2015.11)

Zhang HH, Huang J, Duvel K, Boback B, Wu S, Squillace RM, Wu CL \& Manning BD 2009 Insulin stimulates adipogenesis through the AktTSC2-mTORC1 pathway. PLoS ONE 4 e6189. (https://doi. org/10.1371/journal.pone.0006189)

Zhang CS, Hawley SA, Zong Y, Li M, Wang Z, Gray A, Ma T, Cui J, Feng JW, Zhu M, et al. 2017 Fructose-1,6-bisphosphate and aldolase mediate glucose sensing by AMPK. Nature 548 112-116. (https://doi. org/10.1038/nature23275)

Zhao F, Mancuso A, Bui TV, Tong X, Gruber JJ, Swider CR, Sanchez PV, Lum JJ, Sayed N, Melo JV, et al. 2010 Imatinib resistance associated with BCR-ABL upregulation is dependent on HIF-1alpha-induced metabolic reprograming. Oncogene 29 2962-2972. (https://doi. org/10.1038/onc.2010.67)

Zhou H \& Huang S 2011 Role of mTOR signaling in tumor cell motility, invasion and metastasis. Current Protein and Peptide Science 12 30-42. (https://doi.org/10.2174/138920311795659407)

Zindy P, Berge Y, Allal B, Filleron T, Pierredon S, Cammas A, Beck S, Mhamdi L, Fan L, Favre G, et al. 2011 Formation of the eIF4F translation-initiation complex determines sensitivity to anticancer drugs targeting the EGFR and HER2 receptors. Cancer Research 71 4068-4073. (https://doi.org/10.1158/0008-5472.CAN-11-0420)

Zoncu R, Bar-Peled L, Efeyan A, Wang S, Sancak Y \& Sabatini DM 2011 mTORC1 senses lysosomal amino acids through an inside-out mechanism that requires the vacuolar H(+)-ATPase. Science $\mathbf{3 3 4}$ 678-683. (https://doi.org/10.1126/science.1207056)

Received in final form 19 July 2018

Accepted 1 August 2018

Accepted Preprint published online 2 August 2018 https://jme.bioscientifica.com https://doi.org/10.1530/JME-18-0058 (c) 2019 The authors Published by Bioscientifica Ltd. Printed in Great Britain

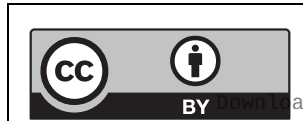

This work is licensed under a Creative Commons Attribution 4.0 Unported License.

ded from Bioscientifica.com at 04/26/2023 10:13:34AM 